\title{
COUNTERVAILING POWER-DIFFERENT RULES FOR DIFFERENT MARKETS? CONDUCT AND CONTEXT IN ANTITRUST LAW AND ECONOMICS
}

\author{
BARBARA ANN WHITE*
}

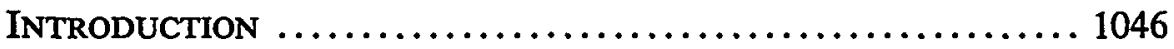

I. JUdicial Notions of Competition................. 1050

A. The Atomistic Model ........................ 1050

B. Antitrust Perspectives of the Supreme Court .......... 1052

1. The Intuitive Atomistic School ................. 1053

2. The Modern Populist School .................. 1055

3. The Modern Market School .................. 1058

4. The Chicago School ....................... 1063

II. The Conundrum of The Status Quo ............... 1065

A. Economic Reasoning and Overlegitimization .......... 1065

B. Conduct over Context ............................ 1066

C. Out of the Conundrum .......................... 1068

III. Countervailing Power Analysis ............... 1070

A. A Theoretical Approach ........................ 1070

B. Countervailing Power Theory ................... 1072

1. Judicial Scrutiny of Countervailing Restraints: The

Cases................................... 1073

a. Countervailing power ................... 1074

i. Arguably illegal restraints ............... 1074

ii. Legal concentrations of power ............. 1078

iii. Redressing negotiating inequality .......... 1079

b. Ensuring competition .................... 1081

* Associate Professor of Law, University of Houston Law Center. B.A. Mathematics, Hunter College, 1969; Ph.D. Economics, Cornell University, 1980; J.D., State University of New York at Buffalo, 1985. I wish to thank Ken Dau-Schmidt, W. Davis Dechert, Eleanor Fox, Charles Goetz, and Jason Johnston, whose thoughts on antitrust scholarship helped sow the seeds for this Article. I would also like to note my conversations with Irene Rosenberg, whose intellectual rigor and interests truly know no bounds, as well as Betty Bock, who was particularly helpful at the final editing stages. I also want to thank an exceptional team of research assistants headed by $T$. Edwin Walker, Class of 1992 . The others were Sidney Edelman, David Jones, Teresa Maines, and Curtis Wunschel, all of the Class of 1993 . The research for this Article was financially supported by the University of Houston Law Foundation. 
- $i$. Are the market's own competitive forces undermined? ........................ 1081

ii. The legal concentration as a competitive check: external pressures ............... 1082

iii. The legal concentration as a competitive check: internal pressures ............... 1085

iv. Self-policing countervailing power .......... 1085

c. Antitrust countervailing restraint evaluations in summary............................. 1087

2. Judicial Treatment of Attempts to Subvert Countervailing Power....................... 1088

IV. Conclusion: The Value of Countervailing Power ANALYSIS ..................................... 1093

\section{INTRODUCTION}

In the last twenty-five years, economic analysis in antitrust law has primarily served to validate much corporate conduct that the courts had previously viewed with great suspicion and often declared illegal. ${ }^{1}$ As a result of the recent trend, many legal barriers to business behavior have been relaxed, ${ }^{2}$ and some complain, ${ }^{3}$ eliminated altogether. ${ }^{4}$ Nevertheless, economic reasoning enables the courts to gain a more sophisticated

1. See, e.g., Donald L. Beschle, "What Never? Well Hardly Ever": Strict Antitrust Scrutiny as an Alternative to Per Se Antitrust Illegality, 38 HASTINGS L.J. 471, 484 (1987) ("During the late 1970s, the expansion of the application of per se rules came to an abrupt halt."); Eleanor M. Fox, The Politics of Law and Economics in Judicial Decision Making: Antitrust as Window, 61 N.Y.U. L. REV. 554, $566-67$ (1986) (criticizing the move toward efficiency analysis in interpreting the antitrust laws as not following Congressional intent); Herbert Hovenkamp, Antitrust Policy After Chicago, 84 Mich. L. REv. 213, 217-18 (1985) (asserting that antitrust law has always used econonics, but the economics used by policymakers in the late 1970 s and early 1980 s was radically different from prior economic models); Thomas A. Piraino, Jr., Reconciling the Per Se and Rule of Reason Approaches to Antitrust Analysis, 64 S. CAL. L. REv. 685, 686 (1991) ("As the Efficiency Model has won over more Supreme Court and lower federal court judges in the past ten years, the per se rule has been applied less frequently, and the rule of reason has achieved a dominant role in antitrust analysis.").

2. For example, see the antitrust treatunent of the following practices: vertical non-price restraints, see Continental T.V., Inc. v. GTE Sylvania, Inc., 433 U.S. 36 (1977) (using econonic analysis favoring interbrand competition over intrabrand competition to overrule Court's previous holding in United States v. Amold, Schwinn \& Co., 388 U.S. 365 (1967), that a manufacturer's nonprice restrictions on its retailers to intrabrand competition with respect to the manufacturer's product were per se illegal); predatory pricing, see Matsushita Elec. Indus. Co. v. Zenith Radio Corp., 475 U.S. 574 (1986) (upholding summary judgment for defendants on basis of economic argument that predatory pricing was an unprofitable business strategy and was therefore not a viable explana. tion for price discounting behavior by firms); tying arrangements, see Jefferson Parish Hosp. Dist. No. 2. v. Hyde, 466 U.S. 2 (1984) (engaging in an economic analysis to conclude that the conduct before thein does not constitute a tying arrangement for antitrust purposes, and Justice O'Connor, in an opinion concurring in judgment, arguing in favor of abandoning per se rulings for tying arrangements and applying instead a rule of reason approach that would incorporate economic reasoning); concerted refusals to deal and group boycotts, see Northwest Wholesale Stationers, Inc. v. Pacific 
and complex understanding of the marketplace, and allows them to discern competitive forces not readily apparent under more traditional analyses of corporate activities. 5

The focus of modern applications of economic reasoning to antitrust concerns has been on the more subtle efficiency or procompetitive dimensions of the scrutinized conduct. 6 When any of these characteristics are discovered, the courts tend to find no antitrust violation. There are two major difficulties with this approach. First, efficiency or procompetitive aspects can almost always be uncovered in any corporate enterprise, creating the potential for legitimizing almost all busmess behavior. ${ }^{7}$ Second, the legal conclusions courts reacli are typically couched in terms of the business practice itself; 8 therefore, once upheld, that practice is validated

Stationery \& Printing Co., 472 U.S. 284 (1985) (limiting the applicability of per se illegality to those instances of exclusive market power, and upholding the practice under rule of reason principles because refusal to deal does not necessarily result in anticompetitive effects); and vertical price restraints, see Business Elecs. Corp. v. Sharp Elecs. Corp., 485 U.S. 717 (1988) (using the economic arguments of interbrand-intrabrand competition to justify limiting those circumstances in which per se illegal vertical price restraints can be found).

3. See, e.g., Ian Shapiro, Richard Posner's Praxis, 48 OHIo ST. L.J. 999 (1987). But see Richard A. Posner, On Theory and Practice: Reply to 'Richard Posner's Praxis,' 49 OHio ST. L.J. 1077 (1989).

4. See infra note 93 (discussing the courts' treatment of exclusive dealerships).

5. The courts have used several concepts over the last 15 years that have developed from economic theory: (1) interbrand competition, see Continental T.V., 433 U.S. at 36; Business Elecs. Corp., 485 U.S. at 717; infra notes 48, 59-60 and aecompanying text; (2) contestable market theory, see Matsushita Elec. Indus, 475 U.S. at 574; Barry Wright Corp. v. ITT Grinnell Corp., 724 F.2d 227 (1st Cir. 1983); infra notes 56, 101-02 and accompanying text; (3) the necessity of restraints to pernit the existence of certain markets, see NCAA v. Board of Regents, 468 U.S. 85 (1985); Broadcast Music, Inc. v. Columbia Broadcasting Sys., Inc., 441 U.S. 1 (1979); infra notes $49-50$ and accompanying text.

6. See infra notes $83-85$ and accompanying text.

7. See infra notes 83-85 and accompanying text.

8. The Court's predilection for constructing its rulings in terms of the conduct, abstracted from the market context, can be seen in both categories of antitrust analyses: the per se rules and the rule of reason approach. It is evident that rules of per se illegality are strictly in terms of the conduct. "[T]here are certain agreements or practices which because of their permicious effect on coinpetition and lack of any redeeming virtue are conclusively presuined to be unreasonable and therefore [per se] illegal without elaborate inquiry as to the precise harm they have caused or the business excuse for their use." Northern Pac. Ry. Co. v. United States, 356 U.S. 1, 5 (1958). The Court also tends to focus its holdings on the conduct even when it engages in a rule of reason analysis that may include an evaluation of the market to assist it in reaching its conclusion:

[T] he rule of reason requires the factfinder to decide whether under all the circumstances of

the case the restrictive practice imposes an unreasonable restraint on competition.

$\ldots$

... Once experience with a particular kind of restraint enables the Court to predict with confidence that the rule of reason will condemn it, it has applied a conclusive presumption that the restraint is unreasonable.

Arizona v. Maricopa County Medical Soc'y, 457 U.S. 332, 343-44 (1982). For a further examination of this phenomenon, sec infra notes $90-95$ and accoinpanying text. 
for most of the spectrum of marketplace scenarios. ${ }^{9}$ Although thus far the more permissive antitrust treatment accorded many restraints has been warranted, the danger is that continued application of economic analysis in this manner will lead to indiscriminate validations of a wide variety of busmess practices. ${ }^{10}$ In addition, many practices will be permitted in an excessively broad range of contexts, some of which, when assessed by nore refined economic standards, could prove to have serious anticonpetitive ramifications. ${ }^{11}$

It is time therefore for the Court to use economic analysis in the antitrust arena in a different way. ${ }^{12}$ The Court must develop a new metlodology for evaluating inarketplace scenarios-one that will allow it to make determinations more consistent with the objectives of the antitrust laws. ${ }^{13}$ In this Article, I propose just such a new analytic framework, one that emphasizes context rather than conduct, thereby avoiding

9. See, e.g., infra note 90 (discussing the courts' treatment of coinmunication of prices and costs of production among competitors).

10. The Court's narrowing the possibility of finding per se illegal vertical price-fixing to preserve the possibility of procompetitive vertical non-price-fixing has certainly raised the question of whether anticompetitive vertical price-fixing will escape antitrust condemnation altogether. See infra note 73.

11. The Court's treatment of predatory pricing in Matsushita Elec. Indus. Co. v. Zenith Radio Corp., 475 U.S. 574 (1986), makes it almost impossible to find that the practice has occurred. The Court based its conclusion on the economic theory, espoused by the Chicago School, that predatory pricing is an unprofitable strategy and will therefore rarely occur. Although the issue has frequently been debated within economic circles, recent developments in economic theory indicate that predatory pricing is more viable than previously believed. See infra note 58. Yet the Court's reasoning in Matsushita makes it unlikely that such activity will be condeunned.

12. A number of scholars have offered new perspectives on the use of economics in antitrust laws. See, e.g., Joseph F. Brodley, The Economic Goals of Antitrust: Efficiency, Consumer Welfare, and Technological Progress, 62 N.Y.U. L. REv. 1020 (1987); Eleanor M. Fox \& Lawrence A. Sullivan, Antitrust-Retrospective and Prospective: Where Are We Coming From? Where Are We Going?, 62 N.Y.U. L. Rev. 936 (1987); Herbert Hovenkamp, Antitrust's Protected Classes, 88 Mick. L. REv. 1 (1989); Thomas G. Krattenmaker \& Steven C. Salop, Anticompetitive Exclusion: Raising Kivals' Costs to Achieve Power over Price, 96 YALE L.J. 209 (1986); Piraino, supra note 1.

13. The debate as to the true objectives of the Sherman Act and antitrust law in general is well docuunented. Is the aim to preserve markets for competitors, or is it to maximize consumer welfare? Is the maximization of consumer welfare the same as promoting economie efficiency?

Some commentators view the antitrust laws as a means to ensure a form of economic dennocracy, that is, to avoid concentration of economic power, to preserve access and presence of other competitors in any particular market and to maintain an equitable distribution of income and wealth. See, e.g., Eleanor M. Fox, The Modernization of Antitrust: A New Equilibrium, 66 CoRNELl L. REv. 1140 (1981); Robert Pitofsky, The Political Content of Antitrust, 127 U. PA. L. REv. 1051 (1979). Others argue for an efficiency criterion as the sole goal so as to maximize consumer welfare. See Robert H. Bork, The ANTtTrust Paradox: A Policy at War WITH ITSELf 51 (1978); Richard A. Posner, ANTITrust Law: AN ECONOMic Perspective 18-22 (1976). Still others take positions in-between. See, e.g., 1 Phillip AREeda \& Donald F. Turner, ANTITrust LaW: AN ANalysis of ANTitrust Principles and Their Application 19 103-113 (1978). There is also disagreement over the correct measure of efficiency and what it means to maxilnize consumer welfare. 
the danger of upholding business practices in dubious circumstances. I demonstrate the efficacy of this model through an antitrust theory of countervailing power, ${ }^{14}$ a theory that can be gleaned froin five Supreme Court cases that span the history of antitrust law since the passage of the Sherman Act. ${ }^{15}$

The countervailing power analysis that I suggest here focuses on the phenomenon of the questionable restraint of trade that emerges in response to an already existing market power that, although legal, nonetheless adversely affects the parties engaging in the challenged conduct. ${ }^{16}$ Even when such restraints conflict with traditional antitrust primciples, my countervailing power analysis upholds their legality, although only in circumscribed and well-delineated circumstances. Unlike the economic approaches that the courts now use (which can lead to overlegitimization), countervailing power analysis is discrete-upholding restraints only in contexts that are truly competitive and in society's interest to maintain. Furthermore, it offers gindelines of salient characteristics that the Court should look for to ensure that the market examined is and will remain truly coinpetitive.

In Part I of this Article, I characterize the four antitrust philosophies that have prevailed on the Court during this century and show how the economists' atomistic model has provided the basis for all four approaches. Part II delineates the probleinatic methodology, developed from the atomistic model, that underhies the Court's current use of economic reasoning and the danger that the methodology creates. In Part III, I suggest an alternative theoretical framework for engaging in economic analysis of antitrust concerns. In that context, I propose a new methodology for evaluating horizontal restraints, which I call countervailing power analysis. Finally, Part IV demonstrates the value and importance of an antitrust theory of countervailing power.

As the debates have continued, the role of economics as an analytic tool seems to have receded to the background. One of the purposes of this Article is to join with a growing miuority and help bring to the forefront once again the power that economic analysis has to make distinctions between competitive and anticompetitive conduct. That awareness of power seems to have faded in much of the discussion of whether and to what extent economics has a place in antitrust law.

14. I take my lead from John Kenneth Galbraith. See John K. Galbraith, AMERICAN CAPITAlisM: The CoNCEPT OF CountervaILING Power 123 (1952) ('[Countervailing power's] development, in response to positions of market power, is pervasive in the economy. . . . The way in which countervailing power operates in these markets is worth examining in some detail."). To my knowledge, no one has applied countervailing power analysis directly to antitrust law.

15. See 15 U.S.C. $\S \S 1-7$ (1988); FTC v. Indiana Fed'n of Dentists, 476 U.S. 447 (1986); Arizona v. Maricopa County Medical Soc'y, 457 U.S. 332 (1982); United States v. Topco Assocs., 405 U.S. 596 (1972); Appalachian Coals, Inc. v. United States, 288 U.S. 344 (1933); Chicago Bd. of Trade v. United States, 246 U.S. 231 (1918).

16. See infra notes $115-55$ and accompanying text. 


\section{Judicial Notions of CoMpetition}

\section{A. The Atomistic Model}

The predominant economic image that underlies the antitrust analyses of differing judicial perspectives mirrors the atomistic model of competition. The atomistic model, ${ }^{17}$ developed by economists, serves both positive and normative functions. ${ }^{18}$ It describes an economic scenario consisting of a large number of buyers and sellers, none of whom can individually affect the market price or output. The model explains how the market forces of competition drive the individual sellers to produce output at the least cost to themselves and to society, and to sell the goods at a price commensurate with those costs. Because of this market pricing mechanism, sellers are also induced to produce goods according to the desires of consumers. Thus the sellers are inclined to operate efficiently and in a manner that maximizes social welfare.

As the atomistic model explains, these production decisions arise directly from the fact that the sellers have no control over market price. Therefore, the only way the sellers can be sure to enhance their profits is to lower production costs. If increased sales will also serve to increase profits, then the sellers must compete witl each other for customers,

17. The Atomistic School reflects a perspective of the marketplace that originated with French economists in the nineteenth century and was later adopted by Adam Sinith for his "invisible hand" characterization of inarket structure. See ADAM SMITH, Wealth of NATIONS (1776); ThE NEW Palgrave, A Dictionary of Economics (John Eatwell et al. eds., 1987). Until the last two decades, the atomistic model has been the primary focus in the development of economic analysis. It portrays the inarket as consisting of inany independent competitors whose behavior is analogized to the functioning of atoms. Although these competitors cannot by themselves control any facet of the marketplace, their interactions determine the outcome of the inarket. Such markets are typically described as ones of perfect or pure competition; the competitors are referred to as price-takers (as opposed to price-setters, such as monopolists). For analyses of perfeet competition in single inarkets, see David M. KRePs, A Course In Microeconomic Theory (1990); Edmond Malinvaud, Lectures on Microeconomic Theory (1972); HAL R. VARIAN, Microeconomic ANALYsis (2d ed. 1984). For analyses of perfect competition for the economy as a whole (known as general equilibrium analysis), see, in addition to the references above, KENNETH J. ARROW \& F.H. HAHN, General Competitive ANalysis (1971); Gerard Debreu, Theory of Value: AN AxioMATIC ANALYSIS OF ECONOMIC EQUILIBRIUM (1959); TJALliNg C. KOOPMANS, ThREe ESSAYS ON THE STATE OF ECONOMIC SCIENCE (1957). The determination that an entire economy could achieve price and output equilibrium when it contained an infinite number of markcts with each consisting of innumerable buyers and sellers was one of the major accomplishments of economic theory in the third quarter of this century. For a less mathematical treatment of these subjects, see Hal R. VARIan, INTERMEdiate Microeconomics: A Modern Approach (2d ed. 1990). See also Herbert Hovenkamp, Economics and Federal ANTITrust LaW 1-49 (1985); F.M. Scherer, Industrial Market Structure ANd Economic Performance (3d ed. 1990).

18. See KoOPMANs, supra note 17, at viii ("The descriptive theory of competitive equilibrium ... and the normative theory of the use of prices for efficient allocation of resources appear as two sides of one coin."); see also Milton Friedman, EsSays in PostTive Economics 3.43 (1953); JoAn Robinson, Economic Philosophy (1962); Paul A. Samuelson, Discussion on Problems of Methodology, AM. ECON. REV., May 1963, at 231-36. 
which in turn requires them to increase quality and lower sales prices. Accomplishing those goals generally demands reduction in production costs as well. ${ }^{19}$ Because lower prices and increased quality of goods are socially desirable, emulating the atomistic structure has been viewed as the ideal way to achieve those ends. ${ }^{20}$

Enterprises can, however, subvert the atomistic process at the expense of the consumers through certain restraints of trade. A classic example is an agreement among competitors to raise prices above market levels to enhance business profits. The agreement prevents the market from determining price levels and turns that control over to the combination of competitors. ${ }^{21}$ To prevent such conduct, in 1890 the Sherman Act was passed.22

19. See supra note 17. Theoretically, once firms reach profit-maximizing levels of output, given their cost structure, they no longer have an incentive to compete for additional customers. Because costs are presumed to rise as production expands beyond a certain point, production in excess of profit-maximizing levels of output implies that the increased costs would exceed the increased revenue and thereby diminish profit levels already achieved. If, however, new cost-savings techmiques are discovered and their full exploitation requires an expansion in sales that, as a result, will further enhance profits, then competition for customers would continue.

20. See, e.g., Joe S. Bain, Barriers to New Competition: Their Character and ConSEQUENCES IN MANUFACTURING INDUSTRIES (1956). Debates over how to measure whether a given market succeeds in the atomistic emulation abound. See, e.g., INDUSTRIAL CONCENTRATION: THE NEw LEARNING (Harvey J. Goldschmidt et al. eds., 1974); Louis Kaplow, Antitrust, Law \& Economics, and the Courts, LAw \& CoNTEMP. ProBs., Autumn 1987, at 181. Krattenmaker \& Salop, supra note 12; William M. Landes \& Richard A. Posner, Market Power in Antitrust Cases, 94 HARv. L. REv. 937 (1981); Richard Schmalensee et al., Landes and Posner on Market Power: Four Responses, 95 HARV. L. REV. 1787 (1981) (debating the proper measure of monopoly power). For case law advocating the atomistic structure, see National Soc'y of Professional Eng'rs v. United States, 435 U.S. 679 (1978):

The Sherman Act reflects a legislative judgment that ultimately competition will produce not only lower prices, but also better goods and services.... The assumption that competition is the best method of allocating resources in a free market recognizes that all elements of a bargain-quality, service, safety, and durability-and not just the immediate cost, are favorably affected by the free opportunity to select among alternative offers.

Id. at 695; see also Catalano, Inc. v. Target Sales, Inc., 446 U.S. 643 (1980) (discussed infra note 44).

21. See, e.g., United States v. Trenton Potteries Co., 273 U.S. 392, 397 (1927) ("The aim and result of every price-fixing agreement, if effective, is the elimination of one form of competition. The power to fix prices... involves power to control the market and to fix arbitrary and unreasonable prices."); United States v. Socony-Vacuum Oil Co., 310 U.S. 150, 221 (1940) ("Those who controlled the prices would control or effectively dominate the market."); see also E. THOMAS SuLLIVAN \& JEFFREY L. HARRISON, UNDERSTANDING ANTITRUST AND ITS ECONOMIC IMPLICATIONS 71-145 (1988); Ian Ayres, How Cartels Punish: A Structural Theory of Self-Enforcement Collusion, 87 Colum. L. REv. 295 (1987).

22. See 21 CoNG. REC. 2456 (1890) (statement of Sen. Sherman) ("The purpose of this bill is to enable the courts of the United States to apply the same remedies against combinations which injuriously affect the interests of the United States that have been applied in the several states to protect local interests."); Appalachian Coals, Inc. v. United States, 288 U.S. 344, 359 (1933) ("The purpose of the Sherman Anti-Trust Act is to prevent undue restraints of interstate commerce, to maintain its appropriate freedom in the public interest, to afford protection from the subversive or coercive influences of monopolistic endeavor."). 
Since the passage of the Sherman Act, the courts, even if not forinally invoking the atomistic model, have been influenced by whether the conduct of the parties before them significantly deviates from the atomistic miage. Thus, the courts have typically focused on the extent to which a large number of sellers are still competing with each other. When the courts find the number sufficiently large, they tend to uphold the business practice in question..$^{23}$ Conversely, as the number of competitive sellers decreases, the courts are inore likely to condemn the conduct as unreasonably impairing competition. ${ }^{24}$ The quantity of sellers is not always dispositive, however; the courts also consider the context in which the restraint operates..$^{25}$ If the courts discover enough procompetitive or efficiency gains, the business practice in question is likely to be upheld, even if there is some deviation from the atomistic franework. These deviations in structure are permitted because the courts believe the firm's production decisions are the same as if it were operating in an atomistic enviroument. ${ }^{26}$ The extent to which courts allow deviations from the atomistic model varies with the philosophy guiding them.

\section{B. Antitrust Perspectives of the Supreme Court}

Scholars typically treat the variety of conflicting antitrust perspectives as divisible into two groups, although there is no agreement as to how that division should be inade. One suggested division is to distinguish between populist and efficiency analyses; ${ }^{27}$ another is to contrast antitrust views by whether they support the goals of economic democracy or of the Chicago School. ${ }^{28}$ Sometimes the two groupings are characterized by whether they advocate imtervention or laissez-faire efficiency. Whatever characterization is chosen, however, the scholarly critiques, evaluations, and debates on antitrust issues seem to grind to a halt in part because the Court's opinions do not fall neatly under one or the other chosen heading. This failing is because there have been nore

23. See, e.g., United States Steel Corp. v. Fortner Enters., Inc. (Fortner II), 429 U.S. 610 (1977); Times-Picayune Publishing Co. v. United States, 345 U.S. 594 (1953).

24. See, e.g., Timken Roller Bearing Co. v. United States, 341 U.S. 593 (1951); United States v. Addyston Pipe \& Steel Co., 85 F. 271 (6tl Cir. 1898), aff'd, 175 U.S. 211 (1899).

25. Beginning in the 1930 s, lowever, some courts were preoccupied with the quantity of buyers and sellers, and refused to consider other economic dimensions that would keep the market competitive. Only when it was determined that a sufficient number of competitors existed were those courts assured that competition was preserved. I characterize sucl courts as subscribing to the Modern Populist philosoplyy. See infra text accompanying notes 40-45.

26. See, e.g., Broadcast Music, Inc. v. Columbia Broadcasting Sys., 441 U.S. 1 (1979); United States v. E.I. Du Pont De Nemours \& Co., 351 U.S. 377 (1956).

27. See 1 AREEDA \& TURNER, supro note 13, at 7-33.

28. See Eleanor M. Fox, The Battle for the Soul of Antitrust, 75 CAL. L. REv. 917, 917-18 (1987). 
than two antitrust perspectives influencing the Court. In fact, one can divide the antitrust philosophies followed by the Supreme Court into four schools: Intuitive Atomistic, Modern Populist, Modern Market, and Chicago School. Because the influence of these philosophies overlaps in time, one can observe the Court in a given period being guided by different approaches in making its antitrust determinations. In recent times, the Court has seeined to be at war with itself, fluctuating from one decision to the next between the philosophies of different schools. ${ }^{29}$

What primarily distinguishes one school from another is the type of and extent to which each engages in economic reasoning. The characteristic they share is that they base their decisions on factors that are consistent with the economists' atomistic model of the marketplace.

1. The Intuitive Atomistic School. The Intuitive Ato1mistic School, as I call it, prevailed in the first third of this century. ${ }^{30}$ It was a reaction to two competing approaches within the theory of pohtical econoiny regarding the regulation of business conduct. One group, the Populists, wanted to preserve a large number of sellers; the second group was willing to sacrifice the quantity of sellers to foster production efficiency

29. Compare, for example, the Court's Modern Populist analysis in Fortner Enters. v. United States Steel Corp. (Fortner I), 394 U.S. 495 (1969), with its Modern Market approach, see infra note 44, in United States Steel Corp. v. Fortner Enters. (Fortner II), 429 U.S. 610 (1977). In Fortner I, the Court established guidelines that essentially dictated that, on remand, the conduct under scrutiny would be held in violation of the Sherman Act. See Fortner I, 394 U.S. at 501-03. When the lower court obliged and the case once again reached the Supreme Court on appeal in Fortner II, the majority then apphed a Modern Market analysis, looking more to the competitive context than to the restraint itself, and reversed the lower court by upholding the business practice. See Fortner $I I$, 429 U.S. at 620-21. The Court reverted to its Modern Populist perspective in Arizona v. Maricopa County Medieal Soc'y, 457 U.S. 332 (1982), but then adopted Modern Market standards when ruling in Monsanto Co. v. Spray-Rite Serv. Corp., 465 U.S. 752 (1984). For a discussion of the Modern Populist and Modern Market approaches, see infra text accompanying notes 40-45 and notes 46-66, respectively.

30. The earhiest decisions refiecting an Intuitive Atomistic approach are also those that first applied a rule of reason standard. The purpose of the rule of reason approach was to permit the courts to consider overall market dynamics, and not just the conduct itself, when ascertaining whether the market remained competitive. The incorporation of a market analysis to address antitrust concerns set the stage for the development of the Intuitive Atomistic philosophy. In particular, Justice White's opinion in Standard Oil Co. v. Umited States, 221 U.S. 1 (1911), viewed as the first statement of rule of reason analysis, incorporated a strong sense of the economics of the marketplace in the proposed assessment of business conduct. Although Justice White acknowledged that some restraints were inherently anticompetitive (thereby opening the door to per se illegality), he asserted that what was of foremost inportance was to determine whether competition in the marketplace as a whole was undermined before declaring a restraint illegal. See id. at 55-65; see also United States v. Southern Pac. Ry. Co., 259 U.S. 214 (1922) (barring defendant railroad from purchasing another railroad when the effect was to suppress the free fiow of competition); United States v. United States Steel Corp., 251 U.S. 417 (1920) (finding defendant subject to too much vigorous competition for there to be anticompetitive effects from its conduct). 
gains through economies of scale. ${ }^{31}$ The Court in this era responded to these views primarily by supporting the Populists' concerns, but tempered this approach with a market analysis to measure the efficiencies created and to gauge the extent to which competitive forces were still effective. ${ }^{32}$

Engaging in a comparatively primitive form of economic analysis, ${ }^{33}$ the Court tended to look at the extent of improvements in the quality and cost of production, and, where relevant, the extent to which prices, output, and the flow of commerce were restrained. So, for example, the Court examined whether the restraint fostered product standardization and improved distribution, ${ }^{34}$ whether it increased access to information and markets among buyers and sellers, ${ }^{35}$ and what percentage of the market was affected by the restraint either in time or scope. ${ }^{36}$ If the restraints were sufficiently limited and the improvenents reasonably significant, the Court tended to find for the defendant; ${ }^{37}$ otherwise, it would

31. For historical analyses of these two competing views, see BORK, supra note 13, at 3-160; Eleanor M. Fox \& Lawrence A. Sullivan, Cases and Materials on Antitrust 22-98 (1989); Herbert Hovenkamp, The Antitrust Movement and the Rise of Industrial Organization, 68 TEX. L. REV. 105 (1989).

32. See, e.g., Frey \& Son, Inc. v. Cudahy Packing Co., 256 U.S. 208 (1921) (discussed infra at notes 36-37); United States v. American Can Co., 230 F. 859 (D. Md. 1916), appeal dismissed, 256 U.S. 706 (1921) (discussed infra at notes 34, 37 and accompanying text).

33. In this era, cconomic analysis itself was at an early stage of development. It had not yet reached the level of sophistication and depth of understanding of corporate conduct afforded by the innovation of mathematical techmiques in the Modern Market period. See infra note 55. Thus the courts were limited to looking at the more salient aspeets of business practices and the extent to which they resembled the atomistic model. See generally Herbert Hovenkamp, The Sherman Act and the Classic Theory of Competition, 74 IowA L. REv. 1019 (1989) (discussing the inanner in which changes in economic ideology have affected judicial interpretation of the Sherman Act).

34. See American Can Co., 230 F. at 894.

35. See, eg., Maple Flooring Mfrs. Ass'n v. United States, 268 U.S. 563 (1925); Unitcd States v. American Linseed Oil Co., 262 U.S. 371 (1923); American Colunin \& Lumber v. United States, 257 U.S. 377, 413-19 (1921) (Brandeis, J., dissenting).

36. See, e.g., United States v. Trenton Potteries, 273 U.S. 392 (1927); Eastern States Retail Lninber Dcalers Ass'n v. United States, 234 U.S. 600 (1914). Compare Frey \& Son, Inc. v. Cudahy Packing Co., 256 U.S. 208 (1921) (holding that the communication and cooperation between manufactnrer and dealer as to resale price was too limited in scope to affect competition overall) with FTC v. Beech-Nut Packing Co., 257 U.S. 441 (1922) (holding that the manufacturer's efforts to ensure that suggested resale prices were adhered to were too far-reaching and suppressed price competition).

37. The Conrt, for example, upheld the inanufacturer's coniniunication of a price floor to dealers in Frey \& Son, see 256 U.S. at 210-11; the consolidation of can manufacturers that took advantage of economies of scale in American Can Co., see 230 F. at 903-04; and the comnunication of sumniary sales data that enabled manufacturers to avoid costly inventory build-up in Maple Flooring, see 268 U.S. at 567. 
condemn the scrutinized practice. ${ }^{38}$ Although economists were still developing the atomistic model, ${ }^{39}$ in this period the Court was intuitively using aspects of that economic depiction of the marketplace to determine whether the real-world conduct at issue violated the goals of the Sherman Act.

\section{The Modern Populist School. The Modern Populist School} emerged in the early 1930s and still holds sway over some Justices on the Court today. ${ }^{40}$ It fully embraced the economists' now well-formed atomistic model. Iroirically, liowever, even though the Justices who adhered to the Modern Populist philosophy formally turned to economics for guidance (including the use of statistical analysis to assess inarket structure), ${ }^{41}$ they apphied the atomistic model so rigidly as to preclude any

38. In American Linseed Oil Co., the Court found that the requirement of the association of manufacturers (comprised of members covering a broad geographical area) that its members report specific details of their prices to which they had to adhere violated the Sherman Act. See 262 U.S. at 390. In Beech-Nut Packing Co., the Court held that the scheme of price communication and enforcement was too extensive and therefore anticompetitive. See 257 U.S. at 455.

39. See sources cited supra note 31 .

40. In recent years, the strongest adherents of the Modern Populist approacl on the Court have been Justices Brennan and Marshall. See, e.g., Continental T.V., Inc. v. GTE Sylvania, Inc., 433 U.S. 36, 71 (1977) (Brennan, J., dissenting, joined by Marslsall, J.) (objecting to the use of efficiency analysis to uphold restraints on intrabrand competition). With their resignations, the only Justices on tlie Court who seem to be influenced by the Modern Populist approach are Justices Stevens and White. See, e.g., Business Elecs. Corp. v. Sharp Elecs. Corp., 485 U.S. 717, 736 (1988) (Stevens, J., dissenting) (decrying majority's refusal to focus on the distinction between "naked restraints" and "ancillary restraints" because of its focus on the distinction between "vertical nonprice restraints" and "vertical price restraints"); Matsushita Elec. Indus. v. Zenith Radio Corp., 475 U.S. 574, 601-04 (1986) (White, J., dissenting) (objecting to the majority's use of economic theory to conclude that predatory pricing could not exist in the case before it).

41. In the early years of the Modem Populist era, courts tended to focus on whether the defendants were engaging iu conduct that seemed, at least on tlie surface, to exclude atomistic competition by eliminating some of the players in the marketplace. See, for example, United States v. First Nat'l Pictures, Inc., 282 U.S. 44 (1930), in which a group of film distributors established local credit committees to determine tlie financial reliability of local theaters to curtail the theater owners' widespread practice of breaching contracts. The distributors agrced not to deal with any theater owner who refused to provide credit information, and, when theater ownership was transferred, not to deal with any owner who refused to lonor the theater's contracts. The lower court had upheld the practice because it circumvented fraudulent trade practices and induced performance of contracts. See United States v. First Nat'l Pictures, Inc., 34 F.2d 815, 818-19 (S.D.N.Y. 1929). Justice McReynolds overruled the lower court and lield the arrangement unlawful on the ground that it "exclud[ed theater owners] fron the opportunity to deal in a free and untrammeled market." First Nat'l Pictures, 282 U.S. at 54.

In the 1960s and 1970s the Court embraced economics more formally when it adopted the "structure-conduct-performance" analysis being developed by certain industrial organization economists-known as the "structuralists." This perspective evaluated the competitiveness of the marketplace by engaging in extensive data analysis to see whether, among otler factors, the defendants' profit performance or the level of concentration in the industry was inconsistent with what the atomistic inodel would predict. Defeudants' conduct would be condemned if the evidence showed undue deviation from the atomistic norm. See, eg., United States v. Philadelphia Nat'l Bank, 374 U.S. 321 
economic analysis that did not focus solely on whether the business behavior deviated from that paradigm. ${ }^{42}$ As a result, no economic evaluations of the efficiency gains achieved or the degree of competitiveness actually existing in the marketplace were entertained.43 Quite frequently, if a restraint enhanced product quality or lowered costs by enabling a

(1963); Brown Shoe Co. v. United States, 370 U.S. 294 (1962). For excellent expositions and analyses of the structuralist era, see Kenneth G. Elzinga, Unmasking Monopoly: Four Types of Economic Evidence, in ECONOMICS \& ANTITRUst Policy 11, 14 (Robert J. Larner \& James W. Meehan, Jr. eds., 1989); James Meehan, Jr. \& Robert Larner, The Structural School, Its Critics and Its Progeny: An Assessment, in Economics \& ANTITRUST Policy, supra, at 179; Tinothy Waters, Antitrust Law and Policy: Rule of Law or Economic Assumptions?, in Economics \& ANTITRust Policy, supra, at 151.

42. The Court in Urited States v. Von's Grocery Co., 384 U.S. 270 (1966), for example, nuade it clear that it viewed the purpose of the antitrust statutes as that of preventing economic concentrations by ensuring the existence of many sinall competitors in the American econoiny. See id. at 276. In American Column \& Lumber Co. v. United States, 257 U.S. 377 (1921), one of the first opinions to augur the Modern Populist approach, the Court focused solely on the danger of horizontal pricefixing that night arise from the communication of price and cost information among trade association nembers. See id. at 411-12. It completely disregarded the fact that there were 400 nembersan nnwieldy number to form a workable price agreenent-and that the information would prevent the meinbers, nuost of whoun were small businessmen, fron making inefficient business decisions by keeping them informed of market conditions. The Court also iguored the competition the association itself faced because it represented only one-third of total industrial production. The intense competitive forces rendered ineffective any anticompetitive impacts arising from the association's information dissennination. Although not Supreme Court cases, the two classic opinions often cited by the Court that exemplify the inflexible application of the atomistic standard are United States v. Aluminum Co. of Am. (ALCOA), 148 F.2d 416 (2d Cir. 1945), and United States v. United Shoe Mach. Corp., 110 F. Supp. 295 (D. Mass. 1953), aff'd per curiam, 347 U.S. 521 (1954), both of which are discussed further infra note 43.

43. In $A L C O A$, the court criticized the defendant for seizing every opportunity to expand its productive capacity (thereby making it more difficult for other firms to enter the industry), particularly when the defendant anticipated a future iucrease in demand. See 148 F.2d at 430-31. Judge Learned Hand did not seem to appreciate that, given the time required to build a new plant and purchase equipinent and machinery, it was in society's interest to have aluminum production already available when deinand increased rather than to suffer through periods of aluminum shortages while the market adjusted. The court also accused ALCOA of "price-squeezing," that is, selling aluminum ingot to sheet-rollers at such a high price that the sheet-rollers could not inatch ALCOA's own rolled sheet price, resnlting in the independents being driven out of business. See id. at 436. Judge Hand apparently did not realize that the only explanation for the "price-squeeze" that was consistent with maximizing profits was that ALCOA inust have been able to roll sheet metal for a lower cost than the independent sheet rollers, resulting in greater profits than would be realized from selling the ingot alone. If that were not the case, then ALCOA would have been selling its aluminum in rolled sheets for a lower net profit than it could have earned froin selling ingots to the sheetrollers without going into the sheet-rolling business altogether, and that would have been an unprofitable business decision.

Judge Wyzanski, in United Shoe, also seemed unaware of the competitive advantages of the activities he criticized. He did not like the fact that United Shoe provided free repairs for its equipment, see $110 \mathrm{~F}$. Supp. at 325, because that closed the market to independent repair services; the modern day autonobile owner can clcarly see the advantages to the consumer of such an arrangement. He also attacked United Shoe's practice of lcasing rather than selling their equipment, and argued that leasing tied purchasers to United Shoe for a longer period of tine, thereby precluding other makers of shoe-manufacturing equipment from reaching those customers. See id at 324-25. 
proportion of sellers to operate in concert, the practice was still condemned and im some cases declared per se illegal, even though the majority of the market was competing effectively with the group. ${ }^{44}$

The Modern Populist School was therefore primarily concerned with the mere presence of combinations and restraints without regard to any other economic consequences. Although the Modern Populist School is umidimiensional im outlook, its impact on the development of antitrust law has been quite significant and has resulted in severe curtailments of perimissible business practices. In particular, this philosophy was responsible for the Court's development of the majority of the rules of per se illegality, ${ }^{45}$ in contrast to the earher Intuitive Atomistic Court's emphasis on a rule of reason approach.

His conclusion is not only dubious, but it ignores the enhancement to competition that leasing creates. A lease term can be no longer than the life of the equipment, and a lessor can break a lease, at some cost, to switch to a preferred product, just as readily as a purchaser can sell equipment, at a loss, to purchase a new brand. In either ease, a customer can, for a price, termmate its use of the equipment and will do so if the new equipment is sufficiently more profitable. Furthermore, potential shoe manufacturers are more hikely to enter the business if their initial capital outlays involve only the expense of leasing equipment rather than the cost of a purchase. As a result, more shoe manufacturers will be in busimess, stimulating competition both in the shoe industry and in the shoemanufacturing equipment industry.

Neither Judge Hand nor Judge Wyzanski considered the competitive or efficiency advantages of the activities they criticized. Instead, they were both concerned with the extent to which the conduct, in the most immediate sense, caused the market structure to sway from the atomistic paradigm.

44. In Catalano, Inc. v. Target Sales, Inc., 446 U.S. 643 (1980), the Court declared per se illegal an agreement among beer wholesalers not to extend free short-term credit to their customer retailers. Because the agreement could have an indirect impact on price, it was viewed as a form of illegal price-fixing. See id. at 650 . The Court explicitly refused to consider the view of the Court of Appeals for the Ninth Circuit that the agreement might actually enhance price competition and therefore should be considered under a rule of reason evaluation. See Catalano, Inc. v. Target Sales, Inc., 605 F.2d 1097, 1099 (9th Cir. 1979).

In Northern Pac. Ry. v. United States, 356 U.S. 1 (1958), the majority examined the seller's requirement that purchasers of its land agree to use the seller's railroad services if they were the lowest priced. The Court ruled that the restriction was a per se illegal tying arrangement. See id. at 7. The Court held that the level of market dominance required was not "anything more than sufficient economic power to impose an appreciable restraint on free competition in the tied product (assuming all the time, of course, that a 'not insubstantial' amount of interstate commerce is affected)." Id. at 11. Although the facts were sparse, the dissent questioned the inajority's conclusion that the seller had market dominance because indications were that the seller owned less than five percent of the land in any given area. See id. at 16 (Harlan, J., dissenting). The lack of market power indicates that the seller was subject to competitive forces and could not have unreasonably foreclosed any part of the market.

45. Of the five categories of per se illegal restraints, four were created by Modern Populist Courts: horizontal price-fixing, see United States v. Socony-Vacuum Oil Co., 310 U.S. 150 (1940); tying arrangements, see International Salt Co. v. United States, 332 U.S. 392 (1947); group boycotts, see Klor's, Inc. v. Broadway-Hale Stores, Inc., 359 U.S. 207 (1959); and horizontal market divisions, see United States v. Topco Assocs., 40 S U.S. 596 (1972). See also Beschle, supra note 1, at 477-98 (reviewing the Court's expansion of per se illegal rules). 
3. The Modern Market School. As society became more sophisticated about the advantages and disadvantages of concentrated corporate conduct, ${ }^{46}$ the judicial door opened to increasingly comprehensive and complex economic analyses that permitted courts to evaluate better the impact of business behavior on market structure and consumer welfare. ${ }^{47}$ A new philosophy of economic analysis emerged that made its first tentative appearance in the judicial arena in the mid-19.60s, ${ }^{48}$ gained momentum in the $1970 \mathrm{~s},{ }^{49}$ and blossomed in the 1980s. ${ }^{50}$ Although the relationship is not readily apparent, the Modern Market School is also primarily based on the atomistic model because it measures defendants' conduct by the extent to which they act as if they are in an atomistic world. ${ }^{51}$

46. See AREeda \& TURner, supra note 13; George J. Stigler, The Organization op INDUSTRY (1968); OLIVER E. WILLIAMSON, MARKETS AND HIERARCHIES: ANALYSIS AND ANTITRUST IMPLICATIONS (1975). Some observe that mainstream America's new sophistication may have been economically motivated. See Fox \& Sullivan, supra note 12, at 945 ("As the American economy slumped in the late 1970s, the pressure for change increased.").

47. See Einer R. Ethauge, The Scope of Antitrust Process, 104 HARv. L. REv. 667 (1991).

48. See, e.g., White Motor Co. v. United States, 372 U.S. 253 (1963) (considering the possibility that interbrand competition could limit the anticompetitive effects of restraints on intrabrand competition).

49. See, eg., Broadcast Music, Inc. v. Columbia Broadcasting Sys., Inc., 441 U.S. 1 (1979) (upholding blanket licensing agreements offered by two agencies, effectively setting prices for all composers and musical performers in the country, on the ground that the licensing arrangement created a market for the members that could not exist before because of high transaction costs); National Soc'y of Professional Eng'rs v. Umited States, 435 U.S. 679 (1978) (invalidating a price restraint on the ground that the marketplace should take care to preserve the quality of services that the restraint was designed to protect).

50. See, eg., Northwest Wholesale Stationers, Inc. v. Pacific Stationery \& Printing Co., 472 U.S. 284 (1985) (finding no group boycott because organization proinoted efficiency and did not have inarket power to generate predominately anticompetitive effects); NCAA v. Board of Regents, 468 U.S. 85 (1984) (refusing to apply per se illegality rule winere product would not exist but for the horizontal restraints); Principe v. McDonald's Corp., 631 F.2d 303 (4th Cir. 1980), cert. denied, 451 U.S. 970 (1981) (declaring the defendant's requirement of both lease and franchise agreement part of an overall business marketing strategy and therefore not a tying arrangement).

51. The role of the atomistic paradigm is obvious when a Modern Market court draws its analyses from Chicago School positions, because the Chicago School derives its arguments froin price theory, which itself is premised on an atonistic framework. See, for example, the Court's adoption in Continental T.V., Inc. v. GTE Sylvania, Inc., 433 U.S. 36 (1937), of the Chicago School argument justifying non-price vertical restraints on the ground that they can promote interbrand competition. For a Chicago School expositor of this position, sec Richard A. Posner, Antitrust Policy and the Supreme Court: An Analysis of the Restricted Distribution, Horizontal Merger and Potential Competition Decisions, 75 Colum. L. REv. 282 (1975). See also Richard A. Posner, The Chicago School of Antitrust Analysis, 127 U. PA. L. REv. 925, 928-33 (1979). Other recent developments in economics on topics such as strategic behavior, technological innovation, and advertising, although more complex in their analyses, still ultimately gauge the conduct's validity by whether it fosters or subverts atoinistic conduct. See Thoinas J. Campbell, Predation and Competition in Antitrust: The Case of Nonfungible Goods, 87 Colum. L. REv. 1625 (1987); Janusz A. Ordover \& Robert D. Willig, An Economic Definition of Predation: Pricing and Product Innovation, 91 YALE L.J. 8 (1981); Thomas 
Like the Intuitive Atomistic School, the Modern Market School looks to the procompetitive and efficiency gains of a particular restraint.52 The Modern Market School, however, draws on more highpowered modern economic reasoning. ${ }^{53}$ In contrast to the Modern Populist School, the Modern Market School tends to rely more on a theoretical economic approach for its legal assessments and less on the extensive and burdensome empirical data studies used by its predecessor. ${ }^{54}$ The Modern Market approach evolved concurrently with an explosion in economic theory that explained the more subtle aspects of competition among industrial organizations. For example, economists have advanced theories about the strategic behavior of corporations concerning product pricing, bundling of goods and services, and technological innovation. These theories deinonstrate that many business strategies that appear to be potentially unreasonable restraints of trade are in fact the very means by which firms compete with each other. ${ }^{55}$ Similarly, an economic theory of contestable markets explains how a corporation can still be subject to competitive forces even when it is the sole firm in an industry: A lone manufacturer will still produce and price goods competitively as long as there is the threat of potential entry by competitors. ${ }^{56}$

These deeper understandings of corporate conduct have led the Court to adapt legal theories consistent with the more comprehensive market analyses emerging in the economics arena. The result has been judicial acceptance of business practices that previously would have been

G. Salop, New Theories of Anticompetitive Exclusion, 56 ANTIrRUST L.J, 57 (1987); Oliver E. Williamson, Delimiting Antitrust, 76 GEO. L.J. 271 (1987).

52. See supra notes 49-50.

53. The Modern Market School has looked below the surface to uncover the efficiency and procompetitive dimensions. The Intuitive Atomistic School looked at the percentage of the market restrained or the obvious cost savings generated by the conduct to measure competitive and effciency effects. When judges point out that tied goods can create economies of scale and efficiently resolve problems of imperfect information as to quality of service, see Jefferson Parrish Hosp. Dist. No. 2 v. Hyde, 466 U.S. 2, 44-45 (1984) (O'Connor, J., concurring), they are applying a more subtle and sophisticated perception of the workings of the market than was available in the Intuitive Atomistic era.

54. See Hovenkamp, supra note 1, at 222-23 ("[A]ntitrust policy makers did not first discover economic theory in the last decade. More accurately, they changed theories.").

55. The major developments in the field of industrial organization in the last 20 years are captured in a series of essays by the leading economists from around the world in the HANDBOOK OF Industrial Organization (Richard Schmalensee \& Robert D. Willig eds., 1989). The two-volume edition is the tenth installment of the HANDBOoKs IN Economics series edited by Nobel Prize winner Kenneth J. Arrow and Michael D. Intriligator. For an excellent and highly accessible review surveying the key subjects and placing them in historical context, see Robert H. Porter, A Review Essay on Handbook of Industrial Organization, $29 \mathrm{~J}$. ECON. LITERATURE 553 (1991).

56. See William J. Baumol et al., Contestable Markets and the Theory of IndusTRY STRUCTURE (1982). 
treated as unlawful.57 For example, the Court now acknowledges that firms may engage in price discounting to introduce new technology or to open new markets, an activity treated in the past as illegal predatory pricing. ${ }^{58}$ Similarly, the Court also permits intrabrand non-price restramts to promote interbrand competition (which it now considers the more efficient goal); 59 previously such intrabrand non-price restraints were declared per se illegal as a derivative form of price fixing. ${ }^{60}$

The changes in substantive standards have also been accompanied and bolstered by significant shifts in the burdens of proof. Thus, since the Modern Market philosophy's ascendancy on the Court, it is now generally accepted that evidence of any procoinpetitive or efficiency gains shifts to the plaintiff the burden of establishing that the anticoinpetitive effects override those benefits. ${ }^{61}$ Moreover, in contrast to the more balanced approach of the Intuitive Atomistic Court, under the Modern

57. See Phillip Areeda, Monopolization, Mergers, and Markets: A Century Past and the Future, 75 CAL. L. REv. 959 (1987); Frank H. Easterbrook, Comparative Advantage and Antitrust Law, 75 CAL. L. REV. 983 (1987).

58. See, e.g., Cargill, Inc. v. Monfort of Colo., Inc., 479 U.S. 104 (1986). For scholarly debates regarding the efficacy and reality of predatory pricing, see Phillip Areeda \& Donald F. Turner, Predatory Pricing and Related Practices Under Section 2 of the Sherman Act, 88 HARV. L. REv. 697 (1975); James D. Hurwitz \& William E. Kovacic, Judicial Analysis of Predation: The Emerging Trends, 35 VAND. L. REv. 63 (1982); John S. McGee, Predatory Pricing Revisited, 23 J. LAW \& ECON. 289 (1980); Oliver E. Williamson, Predatory Pricing: A Strategic and Welfare Analysis, 87 YALE L.J. 284 (1977). Although throughout the last decade one widely held view in economics has been that predatory pricing is not a viable strategy and that deep price discounting by firms is likely to be the result of procompetitive efforts, recent econonic analysis suggests that there arc some scenarios in which pricing policies by firms could have a predatory purpose. See AlEXIS JACQUEMIN, The New Industrial ORganization: MARket Forces aND STRATEgic Behavior (Fatemeh Mehta trans., 1987); Janusz A. Ordover \& Garth Saloner, Predation, Monopolization, and Antitrist, in 1 HANDBOOK OF INDUSTRIAL ORGANIzATION, supra note 55, at 537, 545-62; see also Steven F. Benz, Below-Cost Sales and the Buying of Market Share, 42 STAN. L. REV. 695 (1990); Brenda S. Levine, Predatory Pricing Conspiracies After Matsushita Industrial Co. v. Zenith Radio Corp.: Can an Antitrust Plaintiff Survive the Supreme Court's Skepticism?, 22 INT'L LAW. 529 (1988); Martin S. Simkovic, Judicial Tests to Determine Predatory Pricing Before and After Matsushita, 44 U. MIAMI L. REV. 839 (1990).

59. See Business Elecs. Corp. v. Sharp Elecs. Corp., 485 U.S. 717, 726 (1988) ("[I]nterbrand competition is the primary concern of the antitrust laws.").

60. See Continental T.V., Inc. v. GTE Sylvania, Inc., 433 U.S. 36 (1977); United States v. Arnold, Schwinn \& Co., 388 U.S. 365 (1967).

61. For example, in Monsanto Co. v. Spray-Rite Serv. Corp., 465 U.S. 752, 762-64 (1984), the Court wished to preserve the procompetitive and efficiency effects of vertical non-price restraints upheld in Sylvania. It recognized that the manufacturer, to make the most efficient decisions, must be in continuous communication with its dealers. The Court wanted to preclude the possibility that such communication would be treated as per se illegal vertical price agreements and thus it held that "[t]here must be evidence that tends to exclude the possibility that the inanufacturer and ... distributors were acting independently" for a violation to be found. Id. at 764 (emphasis added). 
Market approach, once procompetitive and efficiency gains are shown, they are unlikely to be successfully rebutted. ${ }^{62}$

Finally, the Modern Market Court has accomplished its imcorporation of the new theoretical economic approach through a broad expansion of rule of reason analysis. ${ }^{63}$ Although the Court has not entirely abandoned the per se illegal rules established during the Modern Populist era, it has enveloped them in preliminary rule of reason analysis that effectively makes per se rules difficult to reach. ${ }^{64}$ Even thougl the development of the Modern Market philosopliy on the Court has been influenced primarily by Chicago School scholarship, it does not necessarily share the goals of the Chicago School-which appears to aim for nearly unfettered corporate activity. ${ }^{65}$ Nonetheless, the manner in which the Modern Market Court currently employs economic analysis has the potential for leading to those results. ${ }^{66}$

The potential for overly broad validation does not necessarily mean that the Court is adopting a Chicago School approach. It is for this reason that the distinction between the Modern Market and Chicago School philosophies is important. Emphasizing efficiency and procompetitive criteria in making antitrust decisions, which I characterize as the Modern Market approach, is quite different from the Chicago School philosophy of presuming that business conduct is procompetitive and efficient

62. See, e.g., John J. Flynn, Current Topics in Antitrust: An Antitrust Allegory, 38 Hastings L.J. 517 (1987); John E. Lopatka, The Case for Legal Enforcement of Price Fixing Agreements, 38 EMORX L.J. 1 (1989); Thomas M. Melsheimer, Economics and Ideology: Antitrust in the 1980s, 42 STAN. L. REV. 1319 (1990); Willard F. Mueller, The Sealy Rcstraints: Restrictions on Free Riding or Output?, 1989 WIS. L. REv. 1255; William H. Page, Optimal Antitrust Penalties and Competitors' Injury, 88 Mich. L. REv. 2151 (1990); Thomas A. Piraino, Jr., The Case for Presuming the Legality of Quality Motivated Restrictions on Distribution, 63 NoTre DAME L. REV. 1 (1988); John P. Drohan, Comment, Tailoring More Efficient Summary Judgment Standards in Antitrust Conspiracy Actions: Apex Oil Co. v. Dimauro, 54 BRookLYN L. Rev. 347 (1988).

63. See, e.g., Thomas G. Krattenmaker, Per Se Violations in Antitrust Law: Confusing Offenses with Defenses, 77 GEo. L.J, 165 (1988); Timothy J. Muris, The New Rule of Reason, 57 ANTITRUST L.J. 859 (1989); Tye G. Darland, Antitrust Law-Vertical Price Restraints: Per Se Illegality or Rule of Reason? Business Electronics Corp. v. Sharp Electronics Corp., 14 J. CoRP. L. 495 (1989).

64. William H. Page, The Chicago School and the Evolution of Antitrust: Characterization, Antitrust Injury, and Evidentiary Sufficiency, 75 VA. L. REV. 1221 (1989).

65. For example, a court adopting the Modern Market philosophy held that "[a]s a matter of law, the absence of proof of market power does not justify a naked restriction on price or output ... [and the restraint] requires some competitive justification even in the absence of a detailed market analysis." NCAA v. Board of Regents, 468 U.S. 85, 109-10 (1984). This standard significantly contrasts with the Chicago School view expressed in Indiana Fed'n of Dentists v. FTC, 745 F.2d 1124 (7th Cir. 1984), rev'd, 476 U.S. 447 (1986), discussed infra at notes 230-33, in which that court stated that without proof of market power the restraint under examination could not be held illegal.

66. See infra notes $83-85,89$ and accompanying text. 
unless certain factors indicate otherwise. ${ }^{67}$ The Modern Market philosophy does not necessarily seek the broad scale validation of every business practice as does the Chicago School; ${ }^{68}$ rather, it is primarily concerned with avoiding invalidations of conduct that are in fact fundamentally procompetitive, even if they do not appear so on the surface. If the Court's use of economic analysis in the last fifteen years has been for that purpose (which I believe to be the case), 69 then the concern that the Court has been deliberately moving antitrust law toward the Chicago School standard is unwarranted.

Such concerns arise because most commentators have not conceptualized a philosophy that adopts efficiency analysis, yet is not the Chicago School. Such a view is understandable, given the significant role that Clicago scholars lave played in persuading the Court to consider more subtle efficiency factors. Most scholars who disagree witl part or all of Chicago School arguments either attack Chicago's economic reasoning, attack the Court's decisions they feel have been unduly influenced by Chicago thought, or, in recognizing a discrepancy between the tenor of the Court's opmions and the Chicago framework, attack the assertion that the Clicago philosophy has prevailed. ${ }^{70}$

Focusing on the validity of the Chicago approach, and its perceived impact on the courts, limits debate decrying its problematic aspects. ${ }^{71}$ Antitrust literature lacks an affirmative non-Chicago characterization of the Court's over-arching economic approach. The result is the deflection of attention away from more positive contributions to the use of economic analyses that inove antitrust law in a direction that can be supported by a broader base of scholars. ${ }^{72} \mathrm{My}$ cliaracterization of the Modern Market School not only offers such a contribution, but it effectively captures the philosophy of economic analysis emerging on the Court over the last fifteen years. This is not to say, lowever, that a nonChicago efficiency standard ensures that the criteria the Court uses to

67. See Frank H. Easterbrook, Workable Antitrust Policy, 84 MICH. L. Rev. 1696, 1701 (1986).

68. See supra note 65.

69. Two possible exceptions are the Court's rulings in Business Elecs. Corp. v. Sharp Elecs. Corp., 485 U.S. 718 (1988) and Atlantic Richfield Co. (ARCO) v. USA Petroleum Co., 495 U.S. 328 (1990). See infra discussion at note 73.

70. See, e.g., Nolan E. Clark, Antitrust Comes Full Circle: The Return to the Cartelization Standard, 38 VAND. L. REv. 1125 (1985); Fox, supra note 1; Hovenkamp, supra note 1; Frederick M. Rowe, The Decline of Antitrust and the Delusions of Models: The Faustian Pact of Law and Economics, 72 GEO. L.J. 1511 (1984); see also Page, supra note 64, at 1254 ("The various references the Court has made to 'economic efficiency' and 'consumer welfare' as goals are too ambiguous in their lexical mcaning and in their context to justify the conclusion that the Court has adopted the Chicago conception of efficiency as its sole standard in antitrust cases.").

71. See, eg., Kaplow, supra note 20; Page, supra note 64.

72. But see Piraino, supra note 1. 
reach antitrust decisions will not lead to overly broad validations. It is that very real possibility that other scholars have either overlooked or treated as an outgrowth of the influence of the Chicago School. The question of excessive legalization of corporate conduct is one of the important concerns of this Article; it is addressed, however, in the more appropriate context of the Court's Modern Market philosophy.

4. The Chicago School. In recent years the Modern Market approach has been the predominant philosophy guiding the Court. With Justice Scalia's appointment to the high tribunal, however, some of the inost recent antitrust decisions of the Court have taken a decidedly different direction. There are indications that the Court may be laying the groundwork for de facto per se legalization of inany business practices. ${ }^{73}$

The premise underlying the Chicago philosophy is that all inarkets fundamentally operate atomistically and that atomistic forces will underinine any efforts by businesses to interfere with them. ${ }^{74}$ The Chicago School is not concerned with aspects of the inarket structure per se, such as the number of sellers, but instead focuses its antitrust inquiry on whether corporate conduct can successfully constrain industrial levels of output. ${ }^{75}$ Proponents of the Chicago School assert that a reduction in industrial output is essential to any anticoinpetitive endeavor, and if the defendants are not able to accomplish that end, then the anticompetitive

73. For example, the Court's decision in Business Elecs. Corp. v. Sharp Elecs. Corp., 485 U.S. 717 (1988), appears to be laying the groundwork for per se legality of vertical price restraints through its requirement of an agreement as to specific price levels to find an illegal vertical price agreement. See, e.g., Jean W. Burns, Rethinking the "Agreement" Element in Vertical Antitrust Restraints, 51 OHIo Sr. L.J. 1 (1990); Rudolph J. Peritz, The "Rule of Reason" in Antitrust Law: Property Logic in Restraint of Competition, 40 HASTINGs L.J. 285 (1989); Barbara A. White, Black and White Thinking in the Gray Area of Antitrust: The Dismantling of Vertical Restraints Violations, 60 GEo. WASH. L. REV. 1 (1991). The Court seemed to continue this trend in Atlantic Richfield Co. (ARCO) v. USA Petroleum Co., 495 U.S. 328 (1990), by requiring the plaintiff to show that the defendant's illegal vertical price-fixing activities setting price ceilimgs constituted predatory pricing before plaintiff could claim antitrust injury. When considered with the Court's position in Matsushita that predatory pricing rarely, if ever, occurred, the $A R C O$ decision appears to make it impossible for a victim of maximuin price-fixing successfully to file suit, thereby eliminating another source of legal sanction against vertical price-fixing. See White, supra. Chicago School proponents have openly advocated per se legality for vertical price-fixing agreeinents for some time. See, e.g. , Richard A. Posner, The Next Step in the Antitrust Treatment of Restricted Distribution: Per Se Legality, 48 U. CHI. L. REv. 6 (1981). For the view that Sharp in fact represents the Court's explicit rejection of the Chicago School view because it did not overturn the per se illegality of vertical price restraints, see Page, supra note 64, at 1254.

74. See, e.g., BoRk, supra note 13, at 116-29.

75. See id. at $179-91$. 
impact of any other restraint will necessarily be compromised. ${ }^{76}$ Furthermore, they believe that industry-wide restraints on output are difficult to maintain. They argue that efforts to raise prices or monopolize markets to the detriment of consumers will not succeed if, for example, firms outside the industry can enter with their own production to compete for the excess profits. Such expansion of output by entering competitors will return prices to their competitive levels. Moreover, the same result will occur if one or more of the parties to the agreeinent have a profit incentive to violate it secretly by expanding output themselves.77

Implicit in the Chicago School philosophy is that, with the exception of restraints that limit output, corporate endeavors are procompetitive by necessity. Because firms are competing in an atomistic world, their efforts must be directed toward wooing customers, which requires providing desirable products and services at the lowest possible prices. ${ }^{78}$ A court adhering to the Chicago School approach will almost invariably conclude that the restraints that firms engage in must exist to serve those ends and therefore must necessarily be efficient. ${ }^{79}$

Thus, the Chicago School writers strongly support the judicial use of analyses that demonstrate how market forces would curtail any suspected anticompetitive effects from business restraints. For instance, they often draw on interbrand-intrabrand analyses and contestable market theories to advocate the validation of scrutimized business practices. ${ }^{80}$ Chicago School scholars also encourage the recognition of procompetitive and efficiency dimensions of corporate conduct, and argue that the presence of those aspects should determine an activity's legality. ${ }^{81} \mathrm{Be}-$ cause these scholars also have a tendency to conclude that output restriction is inherently impossible in nearly every antitrust scenario that they consider, when that viewpoint is considered with the emphasis on

76. See Wesley J. Liebeler, What Are the Alternatives to Chicago?, 1987 DuKE L.J. 879.

77. Frank H. Easterbrook, Vertical Arrangements and the Rule of Reason, 53 ANTITRUST L.J. 135 (1984).

78. Easterbrook, supra note 67 , at $1700-01$.

79. See Herbert Hovenkamp, Rhetoric and Skepticism in Antitrust Argument, 84 MicH. L. REv. 1721, 1723-24 (1986).

80. See, e.g., Wesley J. Liebeler, Intrabrand 'Cartels' Under GTE Sylvania, 30 UCLA L. REv. 1 (1982).

81. See, e.g., Wesley J. Liebeler, 1984 Economic Review of Antitrust Developments: Horizontal Restrictions, Efficiency, and the Per Se Rule, 33 UCLA L. REv. 1019 (1986). Although Chicago scholars formally advocate that antitrust determinations should be based on weighing and balancing the efficiency gains against the efficiency losses, the evaluation of those gains and losses must be done for the most part heuristically. In fact, Chicago scholars, when evaluating any specific conduct, almost invariably find in favor of upholding the conduct because of the efficiency dimensions they have discovered. See, e.g., Yale Brozen, Concentration, Mergers, and Public Policy (1982); Lester G. Telser, A Theory of Efficient CoOperation and Competrtion (1987). 
procompetitive and efficient aspects, there is a tendency for Chicago School followers to uphold every restraint. ${ }^{82}$

\section{The Conundrum of The Status Quo}

\section{A. Economic Reasoning and Overlegitimization}

Whether or not it is the Court's intention, the current applications of economic reasoning im antitrust law may lead inevitably to results that are consistent with Chicago School values, which, some contend, aim to dismantle antitrust regulation altogether. ${ }^{83}$ The economic analysis engaged in today is more sophisticated than it was im the past; it allows the Court to ferret out more subtle elements of competitiveness and efficiency. ${ }^{84}$ Because firms seek to operate efficiently so as to maximize their profits, and because economic analysis is now so discerning, such elements can almost always be found in any corporate endeavor. Thus, because the primary criterion used to determine the validity of econoinic behavior is the presence of any efficiency or procompetitive effects, and those effects are almost always possible to discover, if the Court contimues in this vein, it will necessarily uphold and legitimize nearly every business practice examined..$^{85}$

The intuitive recognition of such a reality has generated a controversy as to whether economic analysis, or, in particular, efficiency criteria, should give way to other antitrust concerns reflected by the atomistic model, such as distributive justice, dispersion of concentrations of power, and economic democracy. ${ }^{86}$ These goals would emphasize the preservation of a large number of sellers in the market at the expense of other

82. See, e.g., Frank H. Easterbrook, The Limits of Antitrust, 63 TEX. L. REv. 1 (1984).

83. See, eg. , Fox \& Sullivan, supra note 12, at 957 ("Despite the consensus that economics can play a supporting role, the Chicago School, in the name of law and economics, has waged ideological warfare, assaulting antitrust itself."); Melsheimer, supra note 62, at 1335 ("II]n the hands of Chicago School proponents, economics has become an engine for an ideology hostile to the operation of antitrust law."); Stephen D. Susman, Business Judgment vs. Antitrust Justice, 76 GEo. L.J. 337, 345 (1987) (asserting that the Supreme Court has been influenced by the Chicago School to the extent that it is "abandoning any attempt to achieve the political goals of antitrust regulation").

84. See supra notes $52-60$ and accompanying text.

85. This is certainly the implication of the Court's standard in Monsanto Co. v. Spray-Rite Serv. Corp., 465 U.S. 752 (1984), which effectively assures that no violation could be found if effciency justifications exist. See supra note 61 . The Court's willingness to create a category of per se legality for vertical price restraints, which are otherwise per se illegal, to avoid any possibility of condemning efficient non-price vertical restraints in Business Elecs. Corp. v. Sharp Elecs. Corp., 485 U.S. 717 (1988), see White, supra note 73, also indicates the extent to which the Court seeks to preserve every element of efficiency that may arise.

86. See Brodley, supra note 12; Robert H. Landes, Wealth Transfers as the Original and Primary Concern of Antitrust: The Efficiency Interpretation Challenged, 34 Hastings L.J. 65 (1982); Rudolph J. Peritz, A Counter-History of Antitrust Law, 1990 DUKE L.J. 263. 
competitive effects. Indeed, to ensure that certain activities will be declared illegal, some argue that the modern economic notions of efficiency and procompetitiveness should be abandoned altogether. ${ }^{87}$

Given how the antitrust tools currently available are being used by the Court in reaching its decisions, the only alteruative to unlimited legalization of problematic business behavior appears to be to forsake modern economic analysis and revert to the Modern Populist approach. That would result in the Court either looking only to the facial characteristics of the particular business practice, or engaging in intensive and burdensome data analysis to determine whether the market sufficiently mirrors the atomistic conception. ${ }^{88}$ The former inquiry leads to inflexible rules that do not consider other competitive and efficiency factors, ${ }^{89}$ and can unnecessarily mipede economic growth. The latter is not only time- and labor-intensive, but yields insights that have limited precedential value. The data results are applicable only to the particular industry in the specific time frame being examined, and therefore economic and legal generalizations caunot be drawn from them.

This apparent restriction of choice either to promote efficiency or to preserve Populist concerns fuels the controversy as to low antitrust decisions shonld be made. Which side one takes depends on the value choice of the individual and seeins to require sacrifice of other important goals.

\section{B. Conduct over Context}

The overlegitimization dilemma is exacerbated by the fact that the Court's rulings are framed primarily in terms of the validity of the conduct. As a result, it appears as if the Court is approving the particular business practice independent of the market in which it arose. ${ }^{90}$ Taken

87. See, e.g., Thomas C. Arthur, Workable Antitrust Law: The Statutory Approach to Antitrust, 62 TUL. L. REv. 1163 (1988); Pitofsky, supra note 13; Lawrence A. Sullivan, Economics and More Humanistic Disciplines: What Are the Sources of Wisdom for Antitrust?, 125 U. PA. L. REv. 1214 (1977).

88. See supra text accompanying notes $40-45$.

89. See supra note 45 and accompanying text.

90. For example, in Maple Flooring Mfrs. Ass'n v. United States, 268 U.S. 563 (1925), the Supreme Court evaluated the validity of the exchange of cost, price, and sales information among the members of a trade association. The information was conveyed in a summarized form, such as average costs and average prices, without specific details as to any particular transaction. The Court upheld the practice after evaluating its impact in the market context in which it arose. See id. at 566-67. The Court, however, couched its ruting only in terms of the practice of exchanging information. See id. at 568. Subsequent courts have upheld that practice in a wide variety of circumstances; indeed, one court stated that Maple Flooring stood for a blanket validation of the exchange of general price and cost information among trade associations absent any concerted intent to control the market. See Wholesale Dry Goods Inst. v. FTC, 139 F.2d 230, 230 (2d Cir. 1943); see also Bolt v. Halifax Hosp. Medical Ctr., 851 F.2d 1273, 1286 (11th Cir. 1988) (deciding that the exchange of information among hospitals concerning a particular doctor's habits is acceptable under Maple 
together with the current use of economic analysis, which validates any conduct with any procompetitive or efficiency effects, ${ }^{91}$ the danger is that the Court's focus on conduct will lead to all business practices in all contexts being upheld. This is not to say that the Court ignores context when it evaluates a specific business practice. Indeed, the Court often looks to the marketplace to assist it in determining the competitive and efficiency effects. The problem is that although there may be special characteristics of the market that give the practice its procompetitive or efficiency dimensions, the Court does not abstract those market characteristics when framing its ruling. Instead, it merely finds whether the practice is competitive or efficient, without linking that conclusion to those characteristics of the context that make it so. ${ }^{92}$ As a result, when that particular business practice appears in subsequent cases, it is often viewed as valid even though the market structure may differ markedly from the original case and may not possess those characteristics that previously rendered the practice competitive or efficient. ${ }^{93}$ Although some

Flooring); Penne v. Greater Minneapolis Area Bd. of Realtors, 604 F.2d 1143 (8th Cir. 1979) (permitting the exchange of brokerage fees and other information on histings among meinbers of board under Maple Flooring even though it could have a negative effect and belonging to the association was necessary for survival); supra note 8 and infra note 93 and accompanying text.

91. See supra text accompanying notes 83-85.

92. See, e.g., Jefferson Parish Hosp. Dist. No. 2 v. Hyde, 466 U.S. 2 (1984). The district court concluded, after trial, that the procompetitive effects outweighed the anticompetitive effects of a contract that tied the services of certain anesthesiologists to the use of the hospital's services. See Hyde v. Jefferson Parish Hosp. Dist. No. 2, 513 F. Supp. 532, 542-54 (E.D. La. 1981). The court of appeals reversed on the ground that the tying arrangement was illegal per se. See Hyde v. Jefferson Parish Hosp. Dist. No. 2, 686 F.2d 286, 291-94 (5th Cir. 1982). The Supreme Court reversed again, but on the ground that there was no evidence that price, quality, supply, or demand for either services had been affected, and therefore the contract did not constitute a tying arrangement. See Hyde, 466 U.S. at 31-32. In a concurring opinion, Justice O'Connor argued that the Court should adopt a rule of reason approach with regard to tying arrangements and acknowledge that the ultimate judicial determination of the restraint's legality in reality depended on its economic inpact. See id. at 34-41 (O'Connor, J., concurring). In fact, the Court could go one step further and develop classifications of market characteristics that render a tying relationship procompetitive.

93. The courts' treatment of exclusive dealerships is a good example of a rule of reason analysis upholding a practice that subsequently led to validations in virtually every context. In United States v. Annold, Schwinn \& Co., 388 U.S. 365 (1967), the Supreme Court stated that "a manufacturer of a product [for which] other and equivalent brands . . . are readily available in the market nay select his customers, and for this purpose he may 'franchise' certain dealers to whom, alone, he will sell his goods." Id. at 376. The Court noted, in addition, that "[i]f the restraint stops at that point-if nothing more is involved than vertical 'confinement' of the manufacturer's own sales of the merchandise to selected dealers, ... the restriction ... would not violate the Sherman Act." Id. Despite that apparent qualification, 10 years later the courts treated exclusive dealerships as if they were essentially per se legal. See GTE Sylvania, Inc. v. Continental T.V., Inc., 537 F.2d 980, 997 (9th Cir. 1976) ("There is a veritable avalanche of precedent to the effect that, absent sufficient evidence of monopolization, a manufacturer may legally grant such an exclusive franchise, even if this effects the elinination of another distributor.") (citations onitted). 
practices are so inherently procompetitive that competition is almost always enhanced regardless of the market structure, ${ }^{94}$ this is not true for all business conduct. ${ }^{95}$

Unfortunately, the problem cannot be resolved simply by the Court's particularizing its rulings to the specific facts before it. To do so would render the Court's holding of limited precedential value. The challenge is to expand the ruling beyond the specifics of the case by acknowledging the predominate aspects of competition and efficiency without, at the same time, creating de facto per se legahization of the practice. Finding that locus is not merely a matter of draftsmanship; it requires a shift im orientation from a paradigin of conduct to a paradigin of context-one that enables the Court to exploit the analytic tools available to evaluate properly the true economic structure of the case.

\section{Out of the Conundrum}

The current emphasis on discovering any procompetitive or efficiency aspects, in conjunction with the tradition of issuing rulings in terms of conduct, limits the effectiveness of modern economic analysis in

Furthermore, the Justice Department's position on exclusive dealerships is that they are generally lawful. See Department of Justice, Vertical RestrainTs Guidelines $\{2.5$ (1985), reprinted in 49 Antitrust \& Trade Reg. Rep. (BNA) No. 1243, at 996 (Dec. 5, 1985); see also SULLIVAN \& HARRISON, supra note 21, at 176-77 (1988) ("Although there are interpretations of Schwinn that leave open the possibility of successfully challenging exclusive dealerships under $\S 1$, in the aftermath of Sylvania and Monsanto such a possibility seems remote.") (footnote omitted); Milton Handler \& Daniel E. Lazaroff, Restraint of Trade and the Restatement (Second) of Contracts, 57 N.Y.U. L. REV. 669, 711 (1982) ("[W] hile it cannot be gainsaid that exclusive representation agreements may offend restraint of trade principles, there must be a showing of significant anticompetitive impact before they will be imvalidated.").

94. Some argne that vertical non-price restraints have a great potential to stimulate interbrand competition and therefore to enhance competition and consumer welfare. See, e.g., Wesley J. Liebeler, Resale Price Maintenance and Consumer Welfare: Business Electronics Corp. v. Sharp Electronics Corp., 36 UCLA L. REv. 889 (1989); Piraino, supra note 62. See generally Betty Bock, An Economist Appraises Vertical Restraints, 30 ANTTrRUST BULL. 117 (1985).

95. Even the Supreme Court has reservations about subsequent applications of its rulings on business practices in disparate contexts. In Hyde, the Court expressed its concern that traditional antitrust tymg analysis, which was developed in the context of product sales, might, when applied to the health care arena, lower the quality of medical services. See Hyde, 466 U.S. at 28 n.47.

The Court's tendency to uphold conduct based on the demonstration of any procompetitive or efficiency aspects has only recently become seriously problematic. Because economic analysis had not yet reached the level of sophistication it has today, the economic effects that scholars were arguing to preserve, and to which the Court was responding, were the most salient ones: interbrand competition, creation of markets, and circumventing transaction costs. Because overcoming barriers to those ends was almost invariably procompetitive, broad-based legal rulings were appropriate. Now, however, that economic analysis is so effective at detecting procompetitive and efficiency effects, it is no longer the case that the presence of those effeets ensures that the market itself is fundamentally procompetitive in the face of the restraint. Thus, the modern Court's standard to validate activity whenever procompetitive or efficiency ramifications can be shown can lead to exces. sive legalization. 
the judicial arena and undermines the Court's ability to use it to make meaningful distinctions regarding unreasonable restraints of trade. Consequently, the Court fails to take full advantage of the power of modern economic developments. 96 The trade-off between unlimited validation of business practices, which seems to occur when the courts use economic analysis, and a more proscribing approach that leads to excessive invalidation and thus impedes economic growth, is not necessary. There is a way to retain economic analysis in antitrust law to promote efficiency gains, and yet still allow the courts to make distinctions between competitive and anticompetitive conduct. In other words, the purported Chicago School goals are not the inexorable result of using economic thinking.

To limit the overly broad effects of rulings based solely on the discovery of any competitive or efficiency aspects of a particular practice, the Court must do a more holistic market evaluation. Such a comprehensive analysis would consider the way that procompetitive and anticompetitive effects interact in a given environment and whether this interaction generates a market structure that is fundanentally procompetitive. The Court could then tie the legitimacy of the business practice to the characteristics of the context that render it competitive, thereby assuring that the business practice, when upheld, would be upheld ouly for those marketplace scenarios that contain these salient characteristics. This would require that the Court identify those generic characteristics of the market that are germane to mamtaining the coinpetitive aspects of the conduct. The Court's ruling would then be tailored to preserving competitive markets and would have generality for precedential purposes; its scope, lowever, would not be limitless. Such an approach can be demonstrated by a countervailing power analysis of restraints of trade. ${ }^{97}$

96. The struggle over whether vertical price-fixing should be per se illegal or legal, for example, ignores the inroads that economists have made in discerning circumstances when vertical price-fixing has procompetitive effects and when it has anticompetitive effects. See, e.g., Thomas J. Hoerger \& Andrew W. Horowitz, Retailers as Buffers: Substituting and Optimal Retail Structure (unpublished manuscript, available from Professor Thomas J. Hoerger, Department of Economics and Business Administration, Vanderbilt University); Greg Shaffer, Capturing Strategic Rent: Full-Line Forcing, Brand Discounts, Aggregate Rebates, and Maximum Resale Price Maintenancc, 39 J. INDUs. EcoN. 557 (1991) (characterizing the profit-maximizing conduct of manufacturers when dcaling with their retailers).

97. For another demonstration of linking the validation of conduct to the correct market context and of how to frame such rulings, see White, supra note 73 (delineating market circumstances when vertical price-fixing should and should not be permitted based on recent developments in economic theory). 


\section{Countervailing Power ANAlysis}

\section{A. A Theoretical Approach}

In order to see a new way of incorporating economic evaluations of corporate conảuct imto antitrust decisions, we must engage in economic analysis within a different framework. First, we need to acknowledge formally that economic evaluations of the efficiency and competitiveness of a specific market need not be undertaken solely through extensive empirical studies. Equally accurate assessments of the coinpetitiveness of particular markets can be achieved through theoretical analyses. Not only are theoretical evaluations as discerning as data investigations, but they can also lead to generalities that transcend the particular industry being examined, providing guidelines that courts can then use with greater ease to assess restraints in other industries..$^{98}$

There is a serious misconception that economic theory is not capable of being dispositive. Theory is viewed as mere speculation that is not equipped to make ultimate determinations of economic reality. Statistical data analysis, on the other hand, is treated as more vahd because it consists of the "cold, hard facts." Actually, data results can be quite speculative because they are sensitive to the empirical methodology einployed and the manner in which it is implemented. Not infrequently, one can achieve widely contradictory results from the same data set with very sinall inodifications in the data inquiry that a priori may seem innocuous. This is not to say that data studies are useless, but rather that they camot be viewed as the ultimate arbiter of the competitiveness of the marketplace to the exclusion of all other forms of economic reasoning. ${ }^{99}$

98. The Court's decision that promoting interbrand coinpetition is a desirable goal for antitrust law was based on theoretical econounic analysis and was first applied in the context of restraints imposed by inanufacturers on their dealers. See Continental T.V., Inc. v. GTE Sylvania, Inc., 433 U.S. 36 (1977). The Court has since extended interbrand coinpetition analysis based on economic theory to a variety of other antitrust contexts. See Atlantic Richfield Co. (ARCO) v. USA Petroleum Co., 110 S. Ct. 1884, 1892 (1990) (antitrust injury); NCAA v. Board of Regents, 468 U.S. 85, 106-07 (1984) (horizontal price restraints); National Soc'y of Professional Eng'rs v. United States, 435 U.S. 679, 694 (1978) (horizontal non-price restrictions).

99. A good example of when theoretical analysis can answer questions that data studies cannot is the determination of whether regulated firms overcapitalize, that is, allocate too much of their productive inputs to industrial plants and equipment. The question of overcapitalization of regulated firm was first raised in Harvey Averch \& Leland L. Johnson, Behavior of the Firm Under Regulatory Constraint, 52 AM. ECON. REV. 1052 (1962), and becaine known as the Averch-Johnson effect. After publication of that article, data analyses were attempted to verify empirically the existence of the phenomenon. See, e.g., William J. Boyes, An Empirical Examination of the AverchJohnson Effect, 14 ECON. INQUIRY 25 (1976); Léon Courville, Regulation and Efficiency in the Electric Utility Industry, 5 BeLL J. ECON. \& MGMT. SCI. 53 (1974); Robert M. Spann, Rate of Return Regulation and Effieiency in Production: An Empirical Test of the Averch-Johnson Thesis, 5 BeLL J. ECON. \& MGMT. ScI. 38 (1974). Courville and Spann engaged in different empirical methodology 
Some suggest that modern economic theory, particularly given its mathematical basis, is beyond the competence of the courts. ${ }^{100}$ Although economic msights are currently developed within a mathematical framework and are thus complex and largely unfamihar to the legal community, they can be translated imto verbal conceptualizations that can be readily grasped and used by the judiciary. For example, the concept of contestable markets was first developed in a very abstract mathematical area of economic theory. ${ }^{101}$ Nevertheless, the notion that the extent to which firms are subject to competitive forces depends on the ease with which new firms can enter the inarket is now a commonplace analysis in antitrust law. ${ }^{102}$

on the same data set, and both found that the Averch-Johnson effect was indeed present. See Courville, supra, at 72; Spann, supra, at 50-51. Boyes made an independent inquiry with the same data set, but found that the data did not support Courville's and Spann's conclusions. See Boyes, supra, at 34.

In 1977, while a graduate student at the California Institute of Technology, Derek McKay sought to resolve the conflicting results by investigating the research methodology used by all three authors. Drawing on his experience as an engineer, McKay found that all threc studies' ineasurement of capital was erroneous. Furthermore, he found that several years of data excluded from those studies that verified the Averch-Johnson effect were critical to the authors' positive results. McKay conducted his own study with expanded data and concluded, contrary to Averch and Johnson's prediction, that regulated firnus were actually undercapitalized. See Derek McKay, Two Essays on the Economics of Electricity Supply (1977) (unpublished Ph.D. thesis, California Institute of Technology). McKay's results were ultimately validated by the use of economic theory in W. Davis Dechert, Has the Averch-Johnson Effect Been Theoretically Justified?, 8 J. EcoN. DYNAMics \& CoNTROL 1 (1984) (showing that regulated firms tend to undercapitalize in relation to unregulated firnis).

100. In United States v. Topco Assocs., 405 U.S. 596 (1972), in rejecting interbrand competition arguments supporting horizontal non-price restraints, Justice Thurgood Marshall noted:

The fact is that courts are of limited utility in examining difficult economic problems. Our inability to weigh, in any meaningful sense, destruction of competition in one sector of the economy against proinotion of competition in another sector is one important reason we have fornulated per se rules [of illegality].

Id. at 609-10 (footnote omitted).

101. See BAumol, supra note 56.

102. Contestable market theory underlies the argument that predatory pricing is not a viable corporate strategy. A successful predatory pricing strategy requires first that the firm drive its competitors out by charging prices below competitive levels, and second, that the predatory firm charge prices above coinpetitive levels to recoup its losses. The firm will not succeed if the market is contestable, that is, if firms can re-enter the inarket relatively easily. If the market is contestable, then as soon as the firm raises its prices above competitive levels (thereby earning the excess profits necessary to compensate its losses), other firms will enter the market and drive prices back down to competitive levels. Under these circumstances, the predatory firm will never recover the losses it incurred during its predation; furthernore, because it will be forced to charge the same competitive price as before, it will never earn more profits than if it had never engaged in the strategy froin the beginming. It was this argument that persuaded the Court in Matsushita to grant summary judgment for the defendant. See Matsushita Elec. Indus. Co. v. Zenith Radio Corp., 475 U.S. 574, 58285,598 (1986). 
Adopting a inore theoretical economic approach would broaden the scope of rule of reason analysis in judicial antitrust decisions. The Modern Populist School argues that the Court should circuinscribe extensive rule of reason inquiry, particularly in those cases that involve economic data, because the resulting decisions do not provide the certainty for the business community that per se rules do. ${ }^{103}$ Although it is of a rule of reason nature, theoretical economic analysis can also provide certainty for the business community, but without creating inflexible rules of illegality or engaging in cumbersoine data investigations. Courts that apply theoretical analyses could develop characteristics that indicate the presence of coinpetition in the inarket structure under examination. If those earmarks were then discovered in other market contexts, they would be strong indicators of the conclusions that the courts would reach.

In reality, courts have been using theoretical reasoning for some time, providing the kind of assurance for the business coinnuunity that is sought by the Modern Populist School. For example, the distinction between interbrand and intrabrand coinpetition was achieved using an apphication of theoretical analysis to determine the coinpetitiveness of vertical non-price restraints. ${ }^{104}$ As a result, and alnost without exception, when inanufacturers engage in non-price vertical restraints in an interbrand context, they will not be found in violation of antitrust laws. ${ }^{105}$ The creation of such well-defined characteristics for determining inarket coinpetitiveness assures certainty without the danger of overlegitimization.

Theoretical analysis thus promotes accuracy, efficiency, and certainty both for the courts and for the business conmununity. Given the value of theoretical analysis, we must now determine how to apply it so that it can properly assist the courts in inaking discriminating choices.

\section{B. Countervailing Power Theory}

The countervailing power approach that I offer not only reveals the advantages of einphasizing theoretical reasoning, it also offers a new tool that delineates characteristics of conpetition in certam market scenarios.

103. See William S. Comanor \& John B. Kirkwood, Resale Price Maintenance and Antitrust Policy, CONTEMP. Pol'y Issues, Spring 1985, at 9, 14.

104. See Continental T.V., Inc. v. GTE Sylvania, Inc., 433 U.S. 36, 52-57 (1977).

105. See, eg., Busimess Elecs. Corp. v. Sharp Elecs. Corp., 485 U.S. 717 (1988); Rice v. Norman Williams Co., 458 U.S. 654 (1982); Murrow Furniture Galleries, Inc. v. Thomasville Furniture Indus., Inc., 889 F.2d 524 (4th Cir. 1989). 
Once these characteristics are found, the courts will know that the market scenario is competitive, thereby obviating the need for excessive concern with whether the conduct, examined by itself, is too fraught with anticompetitive aspects.

Countervailing power analysis focuses on an economic phenomenon in which parties combine im some fashion that raises antitrust suspicion. ${ }^{106}$ This combination is in response to a concentration of market power that adversely affects the parties combining, but which is nevertheless legal. ${ }^{107}$ The question raised is whether the countervailing combination should be considered an illegal restraint of trade. As we have seen, the Court typically evaluates the restraint on its own terms, ${ }^{108}$ looking only to whether there are competitive dimensions to it, assessing it by the extent to which the defendant's conduct emulates the atomistic model. ${ }^{109}$ If a court adopting the Modern Populist philosophy is inaking the determination, the restraint is likely to be invalidated; a court adopting the Modern Market philosophy, however, wonld tend to uphold the restraint. Regardless of its philosophical approach, the Court does not fraine its rnhing in terms of how the market interacts with the restraint. In particular, when the restraint arises as a countervailing force to the legal concentration, the Court's ruling does not reflect whether the legal concentration or other market forces can keep in check any anticompetitive dimensions held by the countervailing combination.

Countervailing power analysis offers one way to assess the restraint's interaction with the marketplace so as to determine whether there are dynamics that will keep the restraint competitive. If those dynamics are discovered, then countervailing power analysis suggests that the practice should be upheld, independent of whether the practice mirrors atomistic behavior. If those dynamics are not found, and the practice is sufficiently anticompetitive by traditional standards, then countervailing power analysis supports its condemnation.

1. Judicial Scrutiny of Countervailing Restraints: The Cases. The four Supreme Court cases that focus directly on countervailing power activity, Chicago Board of Trade v. United States, ${ }^{110}$ Appalachian Coals, Inc. v. United States, ${ }^{111}$ United States v. Topco Associates, Inc., ${ }^{112}$ and

106. See infra notes $115-41$ and accompanying text.

107. See infra notes $142-55$ and accompanying text.

108. See supra notes $90-95$ and accompanying text.

109. See supra notes $17-82$ and accompanying text.

110. 246 U.S. 231 (1918).

111. 288 U.S. 344 (1933).

112. 405 U.S. 596 (1972). 
Arizona v. Maricopa County Medical Society, ${ }^{113}$ point to several key characteristics of the countervailing phenomenon. These features include an arguably illegal restraint of trade that serves to protect powerless individuals froin an exploiting legal concentration, thereby putting thein on an equal footing. My countervailing power approach, however, suggests that in order for the restraint to be declared legal, these characteristics must be accoinpanied by inarket dynamics that preserve coinpetition in spite of the restraint's anticompetitive aspects. Moreover, as we will see, when a countervailing restraint functions competitively, overall coinpetition is inevitably enhanced by its presence. ${ }^{114}$ Thus, iny countervailing power theory argues that whenever a countervailing restramt functions competitively it should be upheld.

\section{a. Countervailing power}

i. Arguably illegal restraints. Each of the four cases examined involves a coinbimation or rule, or an aspect thereof, that has all the eleinents of an illegal restraint of trade. ${ }^{115}$ But whether the Court declares such conduct illegal usually depends on the particular Court's antitrust philosophy. For example, Chicago Board of Trade, a 1918 decision reflecting the Intuitive Atomistic School, concerned a rule inposed by the Commodities Board, which fixed prices for a certain type of grain for a limited time period.116 The question was whether this rule constituted horizontal illegal price fixing. ${ }^{117}$ Even though all the elements of horizontal price fixing were present, ${ }^{118}$ the Court, consistent with the Intuitive Atomistic philosophy, upheld the practice by balancing the extent

113. 457 U.S. 332 (1982).

114. See infra text accompanying notes $238-43$.

115. Three of the cases concerned some aspect of price fixing: Chicago Bd. of Trade v. United States, 246 U.S. 231, 237 (1918) (board setting prices of certain commodities); Appalachian Coals v. United States, 288 U.S. 344, 357-58 (1933) (regional coal miners forming a corporation to set a common price); and Arizona v. Maricopa County Medical Soc'y, 457 U.S. 332, 335-36 (1982) (doctors voting colleetively on fce schedule to use for imsurance purposes). One case, United States v. Topco Assocs., 405 U.S. 596, 612 (1972), involved horizontal territorial and customer restraints limiting intrabrand competition.

116. Chicago Board of Trade, 246 U.S. at 237. The Board fixed the price of "to arrive" grain that arrived during the time period when the exchange was closed. It set the price equal to the day's closing market pricc; that price remained in force overnight until the start of business the following morning. When the new business day began, the price of "to arrive" was once again determined by the market. Id.

117. Id. at 238-39.

118. The Board set the price for "to arrive" grain for all the grain sellers delivering to the Chicago area after business hours, thereby preventing the prices from falling below that set by the market at close. Id. at 237. 
of the restraint against its procompetitive impacts on the market.119 Such a price rule, however, would clearly have been declared per se illegal by a Court following the Modern Populist philosophy. ${ }^{120}$ Indeed, im a case strongly paralleling the pricing restraint in Chicago Board of Trade, the Court in the Modern Populist era did call the activity horizontal price fixing and therefore per se illegal. ${ }^{121}$

Similarly, in United States v. Topco Associates, Inc., ${ }^{122}$ a $1972 \mathrm{Mod}$ ern Populist decision, the Court held that horizontal territorial and custoiner restrictions imposed by an association of regional supermarkets on the inarketing of jointly manufactured private label goods were per se illegal. ${ }^{123}$ The Court condemned the practice, in spite of the strong presence of interbrand competition circuinventing the anticompetitive effects the restraints had on intrabrand competition. ${ }^{124}$ In contrast, in the 1977

119. See id. at 241. The Supreme Court noted the rule's short duration and its applicability to only a limited portion of grain sold. Because the rule assured that grain sellers would not be subjected to price gouging if their grain arrived late at night, the Court reasoned that this certainty would encourage more grain dealers to use the Chicago market and thereby open it up to more competitive activity. For further discussion, sec infra notes 156, 167-74 and accompanying text.

120. See supra notes $40-45$ and accompanying text. The Modern Populists' tendency to focus on the restraint itself to see if it sets prices would almost certainly lead a Modern Populist court to declare the Board's activity per se illegal. The Modern Populists have made it clear that once price fixing is involved, no procompetitive or efficiency arguments will sway them away from finding the activity per se illegal. See, e.g., United States v. Topco Assocs., 405 U.S. 596, 609 (1972) (reversing the district court's judgment and holding iustead that the horizontal restraints in question were per se illegal, stating: "Whether or not we would decide this case the same way under the rule of reason used by the District Court is irrelevant to the issue before us.").

121. See Catalano, Inc. v. Target Sales, Inc., 446 U.S. 643 (1980) (discussed supra note 44). The restraint involved in Catalano-a wholesalers' agreement not to extend short-term credit-did not directly involve price-fixing as did the restraint in Chicago Board of Trade. See id. at 644-47. The Catalano restraint did, however, affect one of the components that contributed to the market price's determination. See id. at 648 . Even though the Catalano restraint was further removed from pricefixing than the Chicago Board of Trade's, the Modern Populist Court nevertheless refused to consider the lower court's market impact analysis under a rule of reason because the restraint indirectly affected prices. Therefore, the Court said, the restraint was per se illegal. See id. at 650; supra note 44.

122. 405 U.S. 596 (1972).

123. See id. at 608 . The regional supermarket chains faced stiff competition from the national supermarket chains because the national chains were marketing high quality goods under their own private labels at a price below national brands. The national supermarkets were able to charge such low prices and yet maintain quality because they were able to take advantage of the cconomies of scale arising from the volume of goods they purchased. None of the individual regional chains, by themselves, were able to achieve such economies. Their only opportunity to do so was to form collectively a larger organization for the sole purpose of manufacturing their own private label, the Topco Brand. The customer and territorial restrictions were imposed so that the member chains would not compete with each other with respect to Topco products. Id. at 598-604.

124. See id. at 610-11. Even though the restrictions prevented the members of Topco from competing with each other, they still had to compete with the national chains, which was why Topco was initially formed. 
Continental T.V., Inc. v. GTE Sylvania, Inc. ${ }^{125}$ case, the Modern Market Court overturned a 1967 ruling that vertical non-price restraints were per se illegal. ${ }^{126}$ The Sylvania Court found that the interbrand coinpetition promoted by vertical non-price restraints was procompetitive and could curtail any anticompetitive effects the restramt had on intrabrand competition. Such restraints, the Court held, should be judged under the rule of reason and upheld when the overall effect was sufficiently procompetitive. ${ }^{127}$ Because the same economic dynamics were also present in the Topco case, one could infer that a Modern Market court would find that, because those horizontal non-price restraints faced strong interbrand procompetitive forces, they should also escape per se condemnation. ${ }^{128}$

That the legality of the restraints depends on the philosophy of the Court is particularly apparent in Arizona v. Maricopa County Medical Society, ${ }^{129}$ a 1982 four-three decision. The case imvolved doctors collectively voting to set maximum prices for their services. ${ }^{130}$ Justice Stevens's opimion for the Court was fundainentally grounded on Modern Populist principles and declared the activity per se illegal horizontal price fixing and therefore illegal.131 The dissent, on the other hand, took a

125. 433 U.S. 36 (1977).

126. See id. at 58 (overruling United States v. Arnold, Schwinn \& Co., 388 U.S. 365 (1967)).

127. See id. at 49-54.

128. A narket criticism of the Topco ruling can be found in BoRK, supra note 13, at 275-79. There is a growing trend toward acknowledging the procompetitive effects of sone horizontal restraints. See cases cited supra notes 49-50. See generally Martin B. Louis, Restraints Ancillary to Joint Ventures and Licensing Agreements: Do Sealy and Topco Logically Survive Sylvania and Broadcast Music?, 66 VA. L. REV. 879 (1980). Although the Court recently upheld its Topco ruling that horizontal narket divisions were per se illegal, see Palmer v. BRG of Ga., Inc., 111 S. Ct. 401 (1990), that case involved two conpetitors who entered an agreenient that was not supportive of interbrand competition. In Palmer, one of the competitors agrced to leave the territory to give the other nionopoly power. In exchange, the first conpetitor received a fee and a percentage of the profits. Id. Immediately upon signing the agreenent, the second competitor increased the pricc of its service by over $250 \%$. Id. at 402 . Clearly this agrecment should be found illegal, whether under a per se analysis or a rule of reason standard. Because the Court appears to be reluctant to overturn formally its decision of per se illegality for horizontal territorial restraints, it could casily follow the path it has used in a number of other cases in which it held the procompetitive effects of the activity were too strong to condemn. This route involves a prehiminary rule of reason analysis to determine whether the activity's procompetitive aspects caused it to fall outside of the proscribed per se illegal category. This certainly is the tack the Modern Market Court took in NCAA v. Board of Regents, 468 U.S. 85 (1984), and Jefferson Parish Hosp. Dist. No. 2 v. Hyde, 466 U.S. 2 (1984), and one that a Modern Market Court could have taken if it had ruled on Topco.

129. 457 U.S. 332 (1982).

130. Id. at 335-36. One of the primary activities of the nedieal society was to establish a schedule of inaxinum fees that participating doctors would agree to accept as full paynent of their services fron insurance companies. Id. at 339.

131. See id. at 351 ('The respondents' principal argument is that the per se rule is inapplicable because their agreenients are alleged to have proconipetitive justifications [of lowering patients' medical bills]. ... The anticonpetitive potential inherent in all price-fixing agreements justifies their facial invalidation even if procompetitive justifications are offered for some."); cf. NCAA, 468 U.S. at 
pure Modern Market approach and pointed to various factors that would militate against the anticompetitive potential of the horizontal price restraint by the doctors. ${ }^{132}$

The results in Chicago Board of Trade, Topco, and Maricopa were consistent with the particular Court's philosophy. That, however, is not always true. The 1933 Appalachian Coals, Inc. v. United States ${ }^{133}$ opinion focused on a combination of small coal miners to set prices of threefourths of the coal production in the region. ${ }^{134}$ Notwithstanding the Modern Populist tendencies of the Court, ${ }^{135}$ and the restraint's strong resemblance to horizontal price fixing by that standard, ${ }^{136}$ the Court upheld the contract. ${ }^{137}$ The decision is often viewed as an aberration, ${ }^{138}$ and perhaps the Justices were swayed by the poverty of the coal miners during the Depression. ${ }^{139}$ As we shall see, however, this imterpretation is correct, but for the wrong reasons. The Court was imtuitively responding to the powerlessness of the group, ${ }^{140}$ a key feature that gives rise to countervailing power analysis.

Thus, the restraints in these cases have the necessiary ingredients to be declared illegal, as seen by the fact that in each case, one court (either the Supreme Court or a lower federal court) found the restraint illegal, whereas the other found sufficient procoinpetitive effects to uphold it. ${ }^{141}$

101 (holding that the horizontal price-fixing agreement before them should not be condemned under a per se illegal standard).

132. See Maricopa, 457 U.S. at 360-61 (Powell, J., dissenting). The dissent pointed to the competition between doctors for patients who were not covered by the relevant insurance programs, the doctors' freedoin to join or withdraw from the organization as they wish, the patients' freedom to choose any doctor whether or not the doctor was a participant, and the insurance coinpanies' incentives to keep fees low. Id.

133. 288 U.S. 344 (1933).

134. See id. at $356-57,371$ (stating that 137 of the 267 miners in the area were members of the Appalachian Coals selling group and were defendants in the action).

135. See infra text accoinpanying notes $\mathbf{1 7 5 - 8 2}$.

136. See Appalachian Coals, 288 U.S. at 373. The coal miners elected to use one agent who would negotiate the selling price of coal for all of thein collectively, thereby removing any incentive for the coal miners to coinpete with each other.

137. See id. at 378.

138. See, e.g., Phillip Areeda, Antitrust ANalysis 454 (3d ed. 1981); Fox \& Sullivan, supra note 31 , at $294-95$.

139. See Fox \& Sullivan, supra note 31, at 294-95. Because of the Depression and organized buyer cooperatives, the coal miners were forced to sell coal at distressed prices.

140. See infra notes $142,157$.

141. See Maricopa, 457 U.S. at 336 (overruling the Ninth Circuit, which upheld the collective voting on price schedules); Topco, 405 U.S. at 597 (overruling the U.S. District Court for the Northern District of Illinois, which had upheld the territorial and customer restraints); Appalachian Coals, 288 U.S. at 347-48 (overruling the U.S. District Court for the Western District of Virginia, which had held the price restraint illegal); Chicago Board of Trade, 246 U.S. at 237-38 (overruling the U.S. District Court for the Northern District of Illinois, which had declared price restraint illegal). 
Whether they are actually invalidated depends on the Court's receptiveness to other procoinpetitive dimensions.

ii. Legal concentrations of power. Countervailing restraints occur because of a market force that undermines the competitive capabilities of the parties who engage in the restraint. The market force typically takes the form of a concentration of power that enables it to take advantage of the parties when they are not in combination. Furtherinore, the inarket force is legal; indeed, its concentration of power is beneficial to society. Thus, in Appalachian Coals, the agency representing the coal miners was formed in response to large buyer cooperatives from the east coast who used their leverage to negotiate extremely low prices with the individual coal miners. 142 Although the buyer cooperatives were able to take advantage of the coal miners, they were nevertheless legal ${ }^{143}$ and served society's interest. The buyers, acting as middlemen between the producers of coal and the ultimate consumers, reduced the transaction costs of such large scale purchases, ${ }^{144}$ thereby promoting efficiency.

Similarly, in Topco, small regional supermarkets formed an association to produce private label brands at lower cost. ${ }^{145}$ Topco Associates was formed in response to the competitive inpact of the national chains marketing their own private label goods. ${ }^{146}$ The national chains were able to inaintain high quality and low prices because of the economies of scale stemming from their extensive buying power; ${ }^{147}$ this concentration of purchasing power was legal and enhanced consuiner welfare. 148

Legal concentrations of power come in various forms and need not stem froin a combination or large economic entity. For exainple, in Chicago Board of Trade, the price-fixing rule was inplemented to limit the negotiating power of the few buyers available to purchase the grain that arrived when the exchange was closed. ${ }^{149}$ In general, cominodity buyers regularly maintained storage facilities for the grain, enabling the individual grain sellers to avoid expensive drayage fees that they would otherwise have incurred if they could not sell to these buyers. ${ }^{150}$ When the

142. Appalachian Coals, 288 U.S. at 364 ("The highly organized and concentrated buying power which they control and the great abundance of coal available have contributed to make the market for coal a buyers' market for many years past.").

143. Id. at 373 .

144. Id. at $369 \&$ n.7.

145. 405 U.S. at $599-600$.

146. Id. at 599 n.3; see supra note 123-24.

147. 405 U.S. at 599 n.3.

148. Id.

149. 246 U.S. at 240 ; see supra notes $116,118$.

150. 246 U.S. at 240 . 
exchange was closed, however, and only a few buyers were available, these buyers gained a negotiating advantage, permitting them to purchase the grain at below-market prices. ${ }^{151}$ Nevertheless, the buyers' maintenance of readily available storage facilities at all times wonld be less costly to society than if each seller had to provide his own grain shelter. Storage services provided by on-site buyers wonld lead to the construction of fewer facilities that were used more frequently than if offsite sellers had made their own provisions. As a result, a smaller amount of society's resources were absorbed for those services-a more desirable outcome. Moreover, when the exchange was open and all the buyers were competing, the effective selling price of those storage services would be correspondingly reduced and would nltimately lead to lower prices for the consumer. Thus, although the commodity buyers could exert monopoly power at night, the services they provided were in society's interest.

The legal concentration of power may also reside in diffuse individuals who have exclusive access to knowledge and expertise of critical value that is being sold in the n1arketplace. In Maricopa, the individual doctors were charging monopoly prices for their services. ${ }^{152}$ The individual patients were in no position to negotiate those fees, and therefore could not take advantage of the atomistic aspects of the doctor's market. ${ }^{153}$ The insurance companies, however, by representing large numbers of patients, could negotiate fee schedules to which the doctors would collectively agree. ${ }^{154}$ It is certainly legal and beneficial for doctors to possess such life-preserving medical knowledge, even though such knowledge gives the doctors the capacity to charge high fees. ${ }^{155}$

iii. Redressing negotiating inequality. In each case, the restraint in question served to put the disadvantaged parties on equal footing with the legal concentration of power. This came about by a rule

151. Id.

152. 457 U.S. at 350 n.20.

153. Id. at $366 \mathrm{n} .13$ (Powell, J., dissenting).

154. Id. at 353-54 nn.28-29.

155. Even though prior to the arrangement in Maricopa the doctors were not engaging in any horizontal agreements, they were still able to charge above-competitive prices, albeit independently of each other. This results from the imperfect information in the market. Because patients do not have an effective mcans of determining the quality of the medical service received, they cannot distinguish one doctor from another on the basis of her competency. Because medical services are essential for maintaining a hcalthy life, price competition among doctors serves no advantage since the patient has no idea if she is giving up anything to see a lower priced physician. In such circumstances, economists have demonstrated that the equilibrium price among physicians will be the monopoly price and not the competitive price, and will occur without any collusion whatsoever. See Mark A. Satterthwaite, Consumer Information, Equilibrium Industry Price, and the Number of Sellers, 10 BELL J. ECON. 483, 483, 485 (1979). 
or entity that protected an otherwise diffuse group that was vulnerable because the members of that group were limited to operating atomistically. Thus, in Chicago Board of Trade, the rule to fix prices for midnight dehiveries of grain ensured that the small grain sellers (who were at the mercy of the few grain buyers) could sell their goods at niarket levels. ${ }^{156}$ In Appalachian Coals, the agency served a similar function by creating a stronger bargaining position for the coal miners when faced with the large buying combines. ${ }^{157}$

In Appalachian Coals and Chicago Board of Trade, the countervailing rule was itself in question. ${ }^{158}$ In Topco and Maricopa, the countervailing combinations theniselves were not in question, but one of the aspects of implementing the countervailing power was alleged to be illegal. In Topco, the association of small regional supermarket chains was formed to protect the individual supermarkets from the marketing strategy of the national chains by enabling the association members to take advantage of economies of scale. ${ }^{159}$ The Court questioned the territorial and customer restrictions that were critical to the effectiveness of the association's purposes. 160 Without these restrictions, the members would have had to engage in intrabrand competition and would have ultimately undermined the interbrand competition that the association was designed to promote. 161

Finally, in Maricopa , a complex case in which the economic dynamics are nore difficult to discern, a niedical foundation was formed to negotiate fee schedules between the insurance companies and the doctors of the community. ${ }^{162}$ The question was whether the doctors' voting collectively on the fee schedule constituted horizontal price fixing. ${ }^{163}$ Although the Supreme Court found it to be a violation, ${ }^{164}$ the collective voting was essential for the fee schedules to be effective so that doctors who did not go along with the price maximums would be effectively foreclosed froin part of their market. ${ }^{165}$ The fee schedules protected the patients who were individually unable to negotiate medical charges that

156. See 246 U.S. at 240 ; supra notes $116,118$.

157. See 288 U.S. at 372 ; supra notes $134-40$ and accompanying text.

158. See Appalachian Coals, 288 U.S. at 356-57; Chicago Board of Trade, 246 U.S. at 237.

159. See United States v. Topco Assocs., Inc., 405 U.S. 596, 599 (1972); supra note 124.

160. See Topco, 405 U.S. at 603-04; supra note 124.

161. See Topco, 405 U.S. at 623 (Burger, C.J., dissenting).

162. See Arizona v. Maricopa County Medical Soc'y, 457 U.S. 332, $353-54$ n.28 (1982).

163. See id. at 352-53.

164. See id. at 356-57.

165. If insurance companies approached doctors individually, as Justice Stevens suggested, see id. at 352 n.26, it is unlikely that any doctor, on her own, would agree to a price-maximun. Each doctor would consider whether she would lose any patients by not agreeing to the maximum. The first doctor approached would know that there would be no cheaper alternatives for the patient to 
would not exceed the maximum the imsurance companies were willing to pay. ${ }^{166}$ Thus, the collective voting in effect protected the diffuse group of patients who were powerless to exploit the competitive possibilities inherent in the doctors' atomistic environment.

b. Ensuring competition. Even though the countervailing conduct serves to protect a diffuse and powerless group, given the potential anticompetitiveness of the countervailing restraint, the Court must still determine whether the market environment will nevertheless remain fundainentally competitive. This can only be done by an assessment of the market context that ascertains whether essential characteristics of competitive forces im the particular market scenario are in place. If the combimation of competitive forces is sufficient to ensure that the intrinsic character of the market is competitive notwithstanding the restraint, then the restraint shonld be upheld for that market context. Although such an evaluation must be conducted on a case-by-case basis, once it has been made, the Court will have a combimation of competitive characteristics and restraints that it knows will ensure competition. These characteristics will be of a generalized nature and therefore can be used in subsequent cases to determine competitiveness; in turn, subsequent cases may themselves yield other salient competitive aspects. An examination of the four countervailing power cases shows us how to look for and weigh the adequacy of those characteristics to ensure a fundanentally competitive market.

i. Are the market's own competitive forces undermined? In Chicago Board of Trade, there was a legal concentration that stimulated a countervailing price restraint, ${ }^{167}$ indicating that countervailing power analysis should be apphed. The Court, however, gave short shrift

select, and therefore the doctor would be in no danger of losing clients. The only impact of agreeing to the maximum would be to reduce the doctor's income. Because this would be the decision process that each doctor would make, the insurance companies would likely be unsuccessful at entering price-ceiling agrecments witl doctors on an individual basis.

On the other liand, if all the doctors voted collectively on the price-ceilings, each individual doctor would have to consider tlie ramifications of not adhering to the agreement. If collective voting was allowed, each doctor's patient would have available to ler a wide range of doctors wlo offered full insurance coverage. In that case, the doctor who did not adliere to the price-maximum would be in danger of losing patients. The discrepancy in the success of individual agreements and collective agrecments would be greater in larger cities than in smaller towns. The smaller the locale, the more accessible the information about the quality of doctors and the prices they charge. Hence, the smaller the locale, the more successful individual contracting would likely be between doctor and insurance companies.

166. See id. at 341.

167. See Chicago Bd. of Trade v. United States, 246 U.S. 231, 235 (1918); supra text accompanying notes $149-51$. 
to the significant role the legal concentration played. ${ }^{168}$ Notwithstanding the lack of exphicit concern with the legal concentration's anticompetitive aspects, the Court seemed to respond intuitively to that issue. Writing on behalf of the Court, Justice Brandeis engaged in an atomistic analysis that acknowledged the price restraint's countervaihing effect. He accurately gauged that the market remained competitive despite, and perhaps because of, the horizontal price restriction. ${ }^{169} \mathrm{He}$ did so by looking at the portion of the market affected by the price rule and noting the strict limitations on its impact. ${ }^{170}$

These limitations on the scope and duration of the price restraint allowed the remaining market to exert its competitive dynamics in a way that would adequately curtail any anticompetitive effects that the rule might have. ${ }^{171}$ In particular, because the percentage of grain affected was small, the grain market itself could overpower any tendency that the price rule might have to raise prices above inarket levels. ${ }^{172}$ In addition, the rule anchored the overnight price to the marketplace, setting it equal to the market price from the prior day, and returning the price's determination to the atomistic market forces upon the rule's expiration the following morning. ${ }^{173}$ Finally, Justice Brandeis noted that the protection provided by the price rule would encourage inore sellers to come to the Chicago market, thereby preserving that market's competitive nature. ${ }^{174}$ Chicago Board of Trade thus teaches us that one way to evaluate the coinpetitiveness of the inarket in the face of countervailing restraints is to look at the extent to which the inarket is affected and deternine whether the unaffected inarket can mitigate the anticompetitive impact of the restramt through the inarket's own procoinpetitive dynamics.

ii. The legal concentration as a competitive check: external pressures. In Appalachian Coals, the Court, consistent with the Modern Popuhist philosophy, did not emphasize the competitive dynamics of the inarket to make its deternination. Instead it looked primarily to the restraint itself, the parties' intent, and the detailed data analysis

168. See Chicago Board of Trade, 246 U.S. at 239-41.

169. See id. at 240 .

170. See id. at 239-41; supra note 119.

171. See Chicago Board of Trade, 246 U.S. at 239-41.

172. Id. at 240 .

173. Id. at 239.

174. See id. at $240-41$. 
presented in evidence. ${ }^{175}$ In spite of that approach, in a nearly unanimous decision, ${ }^{176}$ the Justices upheld the legality of an agency that set prices on behalf of seventy-three percent of all the production in the region. When viewed through the Modern Popuhst prism, this practice is unambiguous price fixing.

Even though the Court acknowledged that the motives fostering a restraint were not determinative of that conduct's legality, ${ }^{177}$ it nevertheless gave as the primary reason for upholding the practice the coal miners' intent to combat industrial difficulties. ${ }^{178}$ Typical of the Modern Populist perspective, Chief Justice Hughes characterized the probleins facing the coal miners-pyramiding, misrepresentations, and credit losses-as evils pervading the industry. ${ }^{179}$ Surprisingly, included among the evils were the organized buyer cooperatives that constituted the legal concentration ${ }^{180}$ and that, as we liave seen, promoted efficiency by reducing the transaction costs of sales. ${ }^{181}$ Expressing concern for the distress in the coal producing industry, the Justices validated tlie price-fixing conduct because they saw it as combatting tliose industrial ills. ${ }^{182}$ Finally, the Court bolstered its conclusion by noting that the data analysis

175. See infra text accompanying notes 177-83.

176. Justice McReynolds was the lone dissenter. See Appalachian Coals, 288 U.S. at 378 (McReynolds, J., dissenting). He remarked only that he thought the lower court reached the correct conclusion in granting the injunction. $I d$.

177. See id. at 372 ("Good intentions will not save a plan otherwise objectionable, but knowledge of actual intent is an aid in the interpretation of facts and prediction of consequences.") (citation omitted).

178. See id.:

With respect to defendant's purposes, we find no warrant for determining that they were other than those they declared. ... The evidence leaves no doubt of the existence of the evils at which defendants' plan was aimed. The industry was in distress. . . . If evil conditions could not be entirely cured, they at least might be alleviated. . . . So far as actual purposes are concerned, the conclusion of the court below was amply supported that defendants were engaged in a fair and open endeavor to aid the iudustry in a measurable recovery from its plight.

See also id. at 376-77 ("[T]he mere number and extent of the production of those engaged in a cooperative endeavor to remedy evils which may exist in an industry, and to improve competitive conditions, should not be regarded as producing illegality.").

179. See id. at 361-63. Many Modern Populist courts had a tendency to frame evaluations in terms of evil or good, nefarious or honest. Although more often they tended to apply the negative characterization to the conduct under examination, in some circumstances, such as here, they would view the market structurc in that light. See, e.g., United States v. United Shoe Mach. Corp., 110 F. Supp. 295, 345-46 (D. Mass. 1953), aff'd per curiam, 347 U.S. 521 (1954) (characterizing United Slioe's conduct).

180. Appalachian Coals, 288 U.S. at 363-64.

181. See supra text accompanying notes 142-44.

182. See Appalachian Coals, 288 U.S. at 376-77. 
presented did not give sufficient indication that prices would be unduly affected. ${ }^{183}$

The economic facts of Appalachian Coals provide significant insight into the more subtle facets of competition that can exist in a 1narket, and that can curtail the anticompetitive effects of a countervailing restraint. Appalachian Coals involved a face-off between the coal producer sellers and the buyers, who themselves were intermediaries between the sellers and the final consuner. ${ }^{184}$ Within the microcosm of the countervailing power market, the struggle was over the profits to be made when the coal was ultimately sold im the consumer market. Each party's respective share of the profits was to be determined by the price at which the producer sold the coal to the imtermediate buyer. Although the agency representing the coal miners would have raised selling prices between the miners and the buying cooperatives, the essential competitive question was not whether those prices would have risen, but whether those higher prices would have caused the prices in the consumer market also to rise. In the Appalachian Coals scenario, the answer was no.

Even though the agency represented three-fourths of the coal production in the region, ${ }^{185}$ it represented only twelve percent of the coal for sale $\mathrm{m}$ the relevant consumer market. ${ }^{186}$ This meant that the final inarket price was set atomistically in the consuiner market in which there were a large number of buyers and sellers. Because the purpose of the buyer cooperatives was to sell the coal in the consunner market, ${ }^{187}$ the consumer market necessarily provided a price ceiling. Clearly, the buyer cooperatives would have been unwilling to pay a higher price to purchase coal than it could get in the consumer inarket. Therefore, even though forming an agency enabled the miners to receive a higher price for their coal, the ensuing price restraint did not affect the consumer.

Thus, Appalachian Coals tells us that if the power being countervailed against can act as a check on the anticompetitive effects of the countervailing restraint, the market-for society's purpose-reinains competitive. Appalachian Coals shows that one way to determine if the legal concentration can act as a check is to ascertain whether it is itself

183. See id. at 368 ("[A]n examination of [the elaborate statistics introduced] fails to disclose an adequate basis for the conclusion that the operation of the defendant's plan would produce an injurious effect upon competitive conditions . . . ."); id. at 373 ("The evidence . . . makes it impossible to conclude that defendants through the operation of their plan will be able to fix the price of coal in the consuming markets.").

184. See id. at 356-58.

185. Id. at 357.

186. Id. The relevant market was all coal production east of the Mississippi River.

187. Id. at 373 . 
subject to competitive forces, outside the countervailing scenario, suffcient to induce it to limit the anticompetitive aspects of the countervailing restraint.

iii. The legal concentration as a competitive check: internal pressures. In Topco, the Court's concern was not with the combination to produce the private label goods, but with the territorial and customer restrictions on selling those goods. ${ }^{188}$ Because the non-price restrictions precluded intrabrand competition, that is, because the members of the association could not compete with each other with respect to the Topco private label brands, ${ }^{189}$ the question was whether the market exerted competitive forces sufficient to limit any undue price rises in Topco goods as a result of those restrictions. In the Topco scenario the answer was yes. As in Appalachian Coals, the legal concentration that Topco was formed to countervail against (here, the national supermarket chains) would limit any such price rises resulting from the territorial and customer restrictions. ${ }^{190}$ In Topco, however, the legal concentration acted as a check because it was also a seller in direct competition with the combining seller parties. Therefore, the competitive force exerted on the legal concentration arose from within the market context. This is im contrast to Appalachian Coals, in which the legal concentration was a buyer that acted as a check because of the competitive forces exerted on it from without. ${ }^{191}$ Thus, whether the legal concentration can obviate the anticompetitive aspects of the countervailing restraint does not depend on whether the competitive forces exerted on it are from within or without the market in which the restramt operates.

iv. Self-policing countervailing power. In Maricopa, the Court acknowledged the consumer benefit derived from insurance compaines negotiating maximum fees witl doctors, ${ }^{192}$ but expressed concern for the potential of maximum fee setting turning into minimum fee setting. ${ }^{193}$ The Court noted that no arguments or evidence were given to justify the doctors' voting collectively on these fees. ${ }^{194}$ Asserting that the

188. See United States v. Topco Assocs., 405 U.S. 596, 603-04 (1972).

189. Id. at 602 .

190. Id. at 622-23 (Burger, C.J., dissenting).

191. See supra text accompanying notes 185-87.

192. See Arizona v. Maricopa County Medical Soc'y, 457 U.S. 332, 352 (1982).

193. See id. at 347.

194. See id. at $352-53 \&$ n.26. 
insurance companies could negotiate prices with the doctors individually, ${ }^{195}$ Justice Stevens declared the collective voting scheme horizontal price fixing and therefore per se illegal. 196

The doctors' collective voting, however, was essential for the countervailing power to be effective in keeping prices down for the patients. The doctors would have had no incentive to agree to maximum fees with the insurance compamies unless they knew that all the other doctors would participate. ${ }^{197}$ Absent collective participation, no doctor would be in danger of losing patients to other doctors who charged lower fees. The question therefore should have been not whether the collective voting had anticompetitive potential, but whether the market structure contained sufficient forces to prevent the doctors, voting collectively, from raising their prices to the monopoly level. The answer in Maricopa was yes because the insurance companies, who were an integral part of the countervailing power, had an incentive to keep fees low. ${ }^{198}$ Although this incentive worked to the patients' advantage, it did not stem from the insurance companies' concern for the patients. It arose because of the insurance companies' concern for marketing their own product that had to compete in an atomistic world, and that in turn required keeping premiums low. ${ }^{199}$ That could only come about if the insurance companies' costs for reimbursing medical bills were also kept low. Thus, the insurance companies were in effect standing in the shoes of the diffuse group of consumers, negotiating lower prices with the doctors. ${ }^{200}$

In Maricopa, the countervailing power consisted of several components: the medical foundation that arbitrated the fees, the insurance companies that agreed to cover the fees, and the doctors who agreed to accept the limitations on the fees. One party to the countervailing power

195. See id. at $353-54 \&$ n.28.

196. See id. at 355-57.

197. See supra note 165 .

198. The Maricopa dissent is the only opinion that reflected some recognition of the countervailing power phenomenon. Justice Powell, in supporting the plan, pointed to the insurance companies' motive to contain costs. See Maricopa, 457 U.S. at 361 (Powell, J., dissenting).

199. Of course, there is the theoretical possibility that the insurance companies and the doctors would conspire together to charge the nonopoly price with the two groups dividing the excess profits between them. This could only come about, however, if all the insurance companies in the nation were involved in the conspiracy. Such cartel activity could not survive as long as there were other insurance companies ready to compete for those excess profits. For all practical purposes, the insurance industry is in fact highly competitive. Maricopa, 457 U.S. at 354 n.29 ("In this case it appears ... that there is competition among imsurance companies . . . ."); Ben Z. Hershberg, Blue Cross Sees Test Ahead, Cour1ER-Journal (Louisville, Ky.), Feb. 24, 1991, at E1 (Competition among insurance companies is "heating up to a fever pitch it hasn't reached for the last two years.").

200. As the dissent noted, insurers may be the ouly parties who have the effeetive power to restrain nedical costs, given the difficulty that patients experience in comparing price and quality for a professional service such as inedical care. See Maricopa, 457 U.S. at 361 (Powell, J., dissenting). 
served as a check on the other party whose interest was at variance with it. In other words, even though the doctors' interest may have been in raising fees, the insurance companies' interest was to keep them as low as possible. Maricopa's insight, therefore, is that the interaction of the components of the countervailing power can serve to limit the anticompetitive potential. Thus, the countervailing power itself can act as its own anticoinpetitive deterrent.

c. Antitrust countervailing restraint evaluations in summary. In general, countervailing power analysis in antitrust law tells us the characteristics to look for before making judgments as to a restraint's legality. The restraint must, of course, contain elements of potential anticompetitiveness for it to come before the Court.201 What creates a countervailing power phenomenon is that the restraint arises in the face of a legal concentration of power. ${ }^{202}$ What should determine legality is the existence of sufficient market dynamics to render the market fundamentally competitive. ${ }^{203}$ The countervailing restraint can be created by a diffuse and powerless group (Appalachian Coals ${ }^{204}$ and Topco ${ }^{205}$ ), or by a third party, either purposely to protect the diffuse group (Chicago Board of Trade ${ }^{206}$ ) or in its own self-interest (Maricopa ${ }^{207}$ ). The competitiveness of the market can be assured either by the market itself (Chicago Board of Trade ${ }^{208}$ ), by the legal concentration being countervailed against (Appalachian Coals ${ }^{209}$ and Topco ${ }^{210}$ ), or by the countervailing power itself (Maricopa ${ }^{211}$ ).

The competitiveness of the countervailing power scenario, lowever, is ultimately possible because it is embedded in a larger atomistic market. As long as those atomistic forces can exert sufficiently direct effects on the countervailing power market, even thougli the countervailing power market is itself not atomistic, it will still be competitive. In each of the cases examined, competition was preserved because of the impact of an atomistic force, either froin within the market (Chicago Board of Trade

201. See supra text accompanying notes $115-41$.

202. See supra text accompanying notes 142-55.

203. See supra text accompanying notes $166-200$.

204. See supra notes 134-40 and accompanying text.

205. See supra note 123 and accompanying text.

206. See supra notes $116-18,157$ and accompanying text.

207. See supra text accompanying notes $162-66,192$.

208. See supra text accompanying notes 167-74.

209. See supra text accompanying notes 183-86.

210. See supra text accompanying notes $189-90$.

211. See supra text accompanying notes 197-200. 
and Topco) ${ }^{212}$ or from outside of it (Appalachian Coals and Maricopa). ${ }^{213}$ Thus, $\mathrm{m}$ one sense the countervailing power analysis is atomistically based, as are all other antitrust approaches. ${ }^{214}$ But because it permits restraints that allow market coinpetitors to act in concert, in another sense it is not.

2. Judicial Treatment of Attempts to Subvert Countervailing Power. Not only does countervailing power analysis have the ability to validate potentially illegal restraints in fundainentally competitive market structures, but it also can guide the Court in condemning efforts by legal concentrations to subvert countervailing efforts that protect vulnerable and diffuse groups. An example of this phenomenon can be seen in a 1986 unanimous Supreme Court decision. In FTC v. Indiana Federation of Dentists, 215 the legal concentration consisted of dentists who had exclusive access to expert knowledge about the dental procedures needed by their patients. ${ }^{216}$ The patients had hittle ineans of determining whether the procedures recommended by the dentists were necessary or adequate, and were therefore a vulnerable and diffuse group. ${ }^{217}$

The countervailing power in this case consisted of insurance compames, which insisted that the dentists include $\mathrm{x}$-rays of the patients' teeth along with their diagnoses. ${ }^{218}$ This would allow the insurance companies to make independent determinations as to whether the recommended procedures were warranted. ${ }^{219}$ The insurance companies' demands could

212. In Chicago Board of Trade, the market in which the countervailing price rule was enforced was able to curtail the anticompetitive effects because the market itself was atomistic. In Topco, the legal concentration (national supermarket chains) could check the anticompetitive potential of the territorial and customer restrictions because the consumer market in which the national and regional supermarkets. competed was atomistic.

213. In Appalachian Coals, the price ceilings exerted on the coal agency by the buyer cooperatives stemmed from the competitive forces faced by the buyers in the atomistic consumer market. Similarly, in Maricopa, the imsurance companies also faced the competitive forces of an atomistic consumer market that induced them to kecp doctors' fees low.

214. See supra notes 30-82 and accompanying text.

215. 476 U.S. 447 (1986).

216. Id. at $461-62$.

217. Id. at 463 .

218. Id. at 449. Group dental insurance was relatively new to Indiana and therefore was of a somewhat experimental nature. The insurance plans typically included two cost-containment provisions: one involving the "predetermimation of claims," the other limiting the insurance companies' obligation to pay benefits only for the "least expensive adequate course of treatment" that was "commonly accepted as providing good dental care." To meet those ends, the insurance companies required that the patient's $x$-rays be enclosed along with the claim form stating the diagnosis. Indiana Fed'n of Dentists v. FTC, 745 F.2d 1124, 1125-26 (7th Cir. 1984).

219. Indiana Fed'n of Dentists, 476 U.S. at 449; see Indiana Fed'n of Dentists, 101 F.T.C. 57, 72 (1983) ("As a result, someone beside the dentist [is] now ... involved in deciding (or at least confirming) a proper treatment plan on which the payment of insurance benefits can fairly be based."). 
be viewed as a means to help patients avoid unnecessary treatment. ${ }^{220}$ On the other hand, such requirements could be considered as an effort to reduce costs by limiting the adequacy of dental care. ${ }^{221}$ Either consequence would enable insurance companies to price premiums more competitively. Nevertheless, regardless of what their incentives might have been, the insurance carriers not only exerted a countervailing restraint on the dentists' monopoly of knowledge, they also operated in a competitive framework that would force them to maintain adequate coverage. As the Court noted, because each company was subject to competition from the others for the sale of its services, each would have to compete through quality of care as well as price. ${ }^{222}$ Thus, collectively, the insurance companies served as their own competitive check on the potential anticompetitive effects (on the kind of dental coverage offered) that might have arisen from their countervailing activities. Under countervailing power analysis, therefore, the demand for x-rays would be considered a legal restraint.

The dentists in the state created a federation and agreed not to send $\mathrm{x}$-rays to the imsurance companies, ${ }^{223}$ thereby forcing the compaines to

220. See Indiana Fed'n of Dentists, 476 U.S. at 449; Indiana Fed'n of Dentists, 101 F.T.C. 57, 72 (1983) ("Insurers, naturally anxious to contain dental health care costs, have not generally been prepared to pay for anything that a dentist recommends. Their covenants to pay dental bills have commonly been limited to payment of a reasonable charge for work reasonably required.") (footnotes omitted).

221. See Indiana Fed'n of Dentists, 476 U.S. at 463 ("The premise of the [dentists'] argument is that ... the provision of $x$ rays will ... . lead to the reduction of costs through the selection of inadequate treatment.").

222. Although the Court did not formally draw on countervailing power analysis, the reference in its opinion to the impact of market competition on the insurance companies' restraints is effectively equivalent to that approach:

Insurers deciding what level of care to pay for are not themselves the recipients of those services, but it is by no means clear that they lack incentives to consider the welfare of the patient as well as the minimization of costs. They are themselves in competition for the patronage of the patients ... and must satisfy their potential customers not only that they will provide coverage at a reasonable cost, but also that coverage will be adequate to meet their customers' dental needs. There is thus no . . . reason to expect dental insurance Id. companies to sacrifice quality in return for cost savings ....

223. Id. at 451 . 
undertake far more expensive procedures to make accurate determinations of the need for care. ${ }^{224}$ Clearly, the dentists' purpose was to undermine the countervailing efforts by the insurance companies, ${ }^{225}$ although it is debatable whether under traditional antitrust analyses the dentists' conduct was illegal.

Under the Modern Populist analysis, adopted by the Federal Trade Commission, ${ }^{226}$ the dentists' agreement could be viewed as a per se illegal group boycott and a concerted refusal to deal.227 Under a Chicago School approach, adopted by the Seventh Circuit to uphold the rule, 228

224. Id. at 456. The Indiana Federation of Dentists claimed that its purpose in refusing to send $x$-rays was to preserve the quality of medical care for its patients by forcing the insurance companies to consider the patients' entire dental history, and not the $x$-rays alone, before reaching any conclusions as to the benefits to be paid. The only means to do this that the Federation would allow, however, was to require the insurance companies to send their own dentists to the offices of the patients' dentists and examine the patients' records there, creating prohibitively high costs to any independent assessment of a dentist's recommended course of treatment. Indiana Fed'n of Dentists, 745 F.2d at 1129-30; see also Indiana Fed'n of Dentists, 101 F.T.C. at 84:

[T]here is unchallenged testimony in this record to the effect that it is not economically feasible and in any event it would be a terrible waste of time to have insurers' professional dental consultants constantly travelling from office to office to talk to dentists (when available) and look at their $X$-rays.

225. The court recognized the dentists' purpose:

The economic interest of dentists in not being 'second-guessed' by their patients' insurers is too plain to need elaboration. The experience of dental health insurers-who, of course, have their own bias-has been that correcting the treatınent plans submitted by dentists in Indiana almost always means slimming them down rather than beefing them up. Experience shows that an alternate benefits clause is a significant cost-containing mechanism.

This is not to say that any large number of dentists deliberately set out to defraud whomever is paying the bill. But where a range of opinion is possible it is not surprising for dentists and bill-payers to have honest disagreements of opinion as to how much dental work is really required in a particular instance. That eeonomic conflict constitutes the background of this case.

Indiana Fed'n of Dentists, 101 F.T.C. at 72-73 (footnotes ounitted).

226. See id.

227. The FTC initially looked only to the agreement itself, see id. at 84 ("As a practical matter, we find that Paragraph 5 of the Manual anounts to a plan by IDA for Indiana dentists to boycott insurers."), without considering any market factors. It focused primarily on the conspiratorial and concerted natnre of the action, see id. at 92 ("[T]he foregoing passages clearly evidence a plan to mobilize Indiana's dentists into an 'evangelistic brigade': brandishing a collective, not an individual refusal to dcal with the insuress serving the state.") (footnote omitted), and noted its extent and effectiveness, see $i d$. at 93-124. It concluded that the dentists' action v/as a concerted refusal to deal and a group boycott and therefore per se illegal. See id. at 124, 127. The FTC acknowledged, however, that the law was still insettled as to what extent professional organizations were exempt from strict per se applications of the mle against group boycotts and concerted refusals to deal and, therefore, might come instead under a rule of reason scrutiny. See id. at 125-26. But the administrative body concluded that even under a rule of reason analysis, the Indiana Federation of Dentists' activities should still be condenned: first, because there were no procompetitive effects offered to offset the anticoinpetitive effects; and second, the preservation of health care argument, which the commission considered a noncompetitive aspect, was not real and was the result of "overly broad 'ethical principles'" that should be disregarded. See id. at 126-27.

228. See Indiana Fed'n of Dentists, 745 F.2d at 1139. 
the dentists' activity could be legal because the evidence failed to preclude the possibility that the Indiana Federation of Dentists lacked market power ${ }^{229}$ or that the dentists would still compete with each other regarding insurance coverage in spite of the restraint. ${ }^{230}$ The Chicago School analysis would dictate that if a judicial assessment cannot exclude the possibility that the restraint has no impact on the market and therefore no anticompetitive effects, then the practice should not be held in violation of the Sherman Act. ${ }^{231}$

The Supreme Court, using a Modern Market analysis, condemned the dentists' actions. ${ }^{232}$ First it noted that there were no procompetitive

229. The Seventh Circuit pointed out that the dentists might be subject to competitive forces from surrounding areas that would make their markets contestable. Indiana Fed'n of Dentists, 745 F.2d at 1141-42. For a general discussion of contestable market theory, see supra note 56 and accompanying text.

230. Indiana Fed'n of Dentists, 745 F.2d at 1141. Typical of a Chicago School approach, the Seventh Circuit panel looked to see if any evidence would support the conclusion that the conduct under question should be upheld. The court first found that the dentists' agreement could not be characterized as a group boycott or a concerted refusal to deal because the dentists ultinately allowed the insurance companies to come to their offices for evaluations. See id. at 1138. Then, under a rule of reason approach, the Seventh Circuit chose to apply a market analysis rather than examine the nature of the agreement itself to determine the anticompetitive effect of the dentists' conduct. See id. at 1138-40. The panel decided that because evidence showed that the member dentists still treated patients covered by the group health insurance policies and permitted in-office reviews of their work, and that the dentists still competed among themselves with regard to their cooperation with the group insurers, therefore the restraint could not be eliminating that coinpetition. See id. at 1143. Finally, the court concluded that the evidence fell far short of proving that the member dentists had sufficient market power effectively to alter it, in spite of strong indications that the Indiana Federation of Dentists comprised $95 \%$ of the dentists in the region. The court argued that the FTC had failed to consider other sources of competition that would affeet the membership. See id. at 1142. Although, hike the F.T.C., the Seventh Circuit did not find any procompetitive effects from the activity, the court gave substantially more weight to the dentists' argument that their purpose was to preserve quality of care. Thus, the Seventh Circuit's analysis was consistent with the Chicago School approach: It engaged in a market analysis rather than focusing on the nature of the conduct itself, and it considered whether output could be successfully restrained by acknowledging the possibility that the dentists were subject to competition from sources other than themselves. Upon finding no anticonpetitive effect from these examinations, the court concluded that the practice should be upheld. For a general discussion of the Chicago School approach, see supra notes 73-82 and accompanying text.

231. See supra notes 73-82, 229 and accompanying text. In effect, this stringent standard is very similar to the one created by the Supreme Court in Monsanto Co. v. Spray-Rite Serv. Corp., 465 U.S. 752 (1984), in which the Court held that to find a concerted action between manufacturer and dealer, "[t]here must be evidence that tends to exclude the possibility that the manufacturer and nonterminated distributors were acting independently." Id. at 764 (emphasis added). Although such a strict standard may be appropriate when questioning the termination by a manufacturer of one of its dealers when the manufacturer is subjeet to significant interbrand competition, it is arguable whether the standard is appropriate in the Indiana Federation of Dentists case given traditional antitrust concerns.

232. See FTC v. Indiana Fed'n of Dentists, 476 U.S. 447, 465 (1986). The Supreme Court dismissed for several reasons the Seventh Circuit's arguments for concluding that competition among dentists for cooperation with third party insurers was not foreclosed. In addition to "common sense 
dimensions to the dentists' agreement.233 The Court asserted that the dentists' efforts to disrupt the market for quality of services was equivalent to interfering with the functioning of the price-setting mechanisin itself. ${ }^{234}$ In each case, the result would have been prices that were higher because of the dentists' agreenent. Thus, by engaging im a rule of reason analysis that mcluded a sophisticated economic assessinent of the restriction's inarket impact, the Modern Market Court found the dentists' activities to be an illegal restraint of trade. ${ }^{235}$ Through the opinions of three adjudicating bodies-the Federal Trade Commission, the Seventh Cirćuit, and the Suprene Court-we see once again how, under traditional antitrust principles, the legality of the rule depends on the philosophy guiding the deciding tribunal.

Although the countervailing power analysis would reach the saine result that the Supreme Court did in Indiana Federation of Dentists, its reasoning would be premised on different principles. Countervailing power analysis would find the insurance companies' efforts a countervailing power because it protected a diffuse, powerless group from a legal concentration that exploited that group. ${ }^{236}$ The analysis would also determine that the insurance companies' restraints were legal because the restraint was subject to competitive forces that would limit any anticoinpetitive effect. ${ }^{237}$

It is evident in Indiana Federation of Dentists that the countervailing power enhances competition and promotes social welfare. Therefore, $\mathrm{m}$ addition to upholding those kinds of restraints, countervailing power analysis would also suggest that efforts by the legal concentration

and economic theory" dictating support for the finding that competition was in fact restrained, Justice White found the factual evidence overwhelming that there was an effective concerted refusal to deal with the insurance companies. See id. at 456. In particular, he noted the ease with which the insurance companies obtained the X-rays in regions where the Indiana Federation of Dentists did not operate. The Court also found unpersuasive the lower court's assertion that competition was not foreclosed by the agreement because the member dentists ultimately made the $\mathrm{x}$-rays available to the insurance companies, albeit under more costly circumstances. See id. at 455-57. After rejecting the Seventh Circuit's Chicago School analysis, Justice White proceeded to evaluate whether the practice was an unreasonable restraint of trade under Modern Market guidelines.

233. See id. at 459. The Court's observation on this point was consistent with those of the Seventh Circuit and of the Federal Trade Commission. See supra notes 225, 228.

234. See Indiana Fed'n of Dentists, 476 U.S. at 459.

235. Because it found no procompetitive impact, the Court avoided the Modern Market's tendency to uphold the practice automatically whenever such effects were found. The Court was therefore able to employ the more balanced aspects of the Modern Market approach and find the restrictions on $\mathrm{x}$-ray submissions anticompetitive.

236. See supra text accompanying notes 154-65.

237. See supra text accompanying notes 166-200. 
to undermine the impact of the countervailing restraint should be condemned. Although the Supreme Court seemed to recognize this intuitively in Indiana Federation of Dentists, its approach does not ensure that similar countervailing power scenarios will be treated the same way in the future. Only if there is a conscious application of countervailing power analysis will sucli conclusions be reached consistently.

\section{Conclusion: The Value of Countervailing Power ANALYSIS}

Given the potential anticompetitive aspects of countervailing power restraints, one might ask why they sliould be permitted merely because competition can still be assured in their presence. Countervailing power restraints arise, lowever, to preserve and enhance competition and social welfare that would otherwise be diminished.

In Chicago Board of Trade, for example, given the lack of control over the time of dehivery to the Chicago area, grain sellers might have gone to other markets if the price rule were not imposed.238 The resulting reduction in the competitiveness of the Chicago market would have adversely affected those consumers who relied on it. In Appalachian Coals, the price to the coal miners was so low without tlie agency tliat some coal miners were being driven out of busmess, ${ }^{239}$ decreasing the number of sellers who could compete in the marketplace. In Topco, if the regional chains could not effectively compete with the national chains, they also miglit have been driven out of business, ${ }^{240}$ resulting in reduced coinpetition among supermarkets and higher prices for consumers. ${ }^{241}$ In Maricopa, the countervailing power arrangement would ultimately lower prices for patients ${ }^{242}$ and enable them to consume more medical services, which would produce an expansion of output and an increase in social welfare. Given the improvements in society's economic well-being that countervailing power brings about, those restraintswhen embedded in a sufficiently competitive environment-should not be barred by antitrust law.

Countervailing power analysis is also valuable because it provides a legal basis for courts to permit economic responses by exploited groups that are tailored to the anticompetitive aspects of otherwise legal behavior. If we relied solely on the courts to redress the problematic aspects of the legal concentration, the legal response would likely be inadequate or

238. See Chicago Bd. of Trade v. United States, 246 U.S. 231, 239.40 (1918).

239. See Appalachian Coals, Inc. v. United States, 288 U.S. 344, 364 (1933).

240. See United States v. Topco Assocs., Inc., 405 U.S. 596, 605 (1972).

241. See id. at 624.

242. See Arizona v. Maricopa County Medical Soc'y, 457 U.S. 332, 351 (1982). 
overly broad. Either the courts would hold the concentration legal and therefore beyond the reach of antitrust laws, or they would attempt to carve out a rule to regulate the troublesome conduct and declare it illegal. The latter approach has the potential of overinvalidation because legal rules barring conduct tend to be insensitive to the particulars of a given economic situation. Because countervailing power restraints arise in response to a specific economic problem, they are inherently focused, and efficiently address only the problematic behavior. ${ }^{243}$ Because legal countervailing power restraints are by definition operating competitively, there is no risk of overly broad effects stemming from them. Thus, countervailing power and countervailing power analysis fill a vacuum in economics and law. The countervailing power responds to an economic vacuum created by a legal concentration of power, and countervailing power analysis provides missing guidelines for the Court to permit such conduct when consistent with antitrust goals.

Finally, countervailing power analysis should appeal to all the antitrust philosophies currently represented on the Court. It clearly promotes competition and efficiency, which are the primary concerns of both the Modern Market and the Chicago Schools. It should also appeal to the Chicago School because it allows more economic behavior to be declared legal. In addition, because it permits distributive justice, that is, access to industrial profits by a larger number of market participants, it should appeal to the Modern Populist School.

Countervailing power analysis provides a new direction for the legal use of economic reasoning in antitrust law. It pernits the Court to broaden its focus beyond particular conduct and allows it to use economic theory that exploits the full power of economic reasoning. As a result, the effectiveness of judicial scrutiny is enhanced through the process of tying evaluations of business conduct to the contexts in which they operate.

243. Judge Easterbrook discusses the comparative advantage that markets have over judicial rulings in correcting anticompetitive aspects of business conduct in Easterbrook, supra note 57. The question is, of course, when can we rely on the market to do so? Countervailing power analysis identifies well-defined circumstances in whieh we can trust the marketplace to remedy an economic barrier. The Chicago School approach tends to lean on a more unconditional faith in marketplace corrections per se, as reflected in Judge Easterbrook's essay. 